\title{
Spirocyclic Motifs in Natural Products
}

\author{
Evgeny Chupakhin ${ }^{1}$, Olga Babich ${ }^{1,2}$, Alexander Prosekov ${ }^{2}$, Lyudmila Asyakina ${ }^{2}$ and \\ Mikhail Krasavin 1,3,* \\ 1 Immanuel Kant Baltic Federal University, 236016 Kaliningrad, Alexandra Nevskogo 14, Russia; \\ chupakhinevgen@gmail.com (E.C.); olich.43@mail.ru (O.B.) \\ 2 Kemerovo State University, 650000 Krasnaya, Kemerovo, Russia; rector@kemsu.ru (A.P.); \\ alk_kem@mail.ru (L.A.) \\ 3 Saint Petersburg State University, 199034 Saint Petersburg, Russia \\ * Correspondence: m.krasavin@spbu.ru; Tel.: +7-9313617872
}

Academic Editor: José Rubén Tormo

Received: 17 October 2019; Accepted: 12 November 2019; Published: 17 November 2019

check for updates

\begin{abstract}
Spirocyclic motifs are emerging privileged structures for drug discovery. They are also omnipresent in the natural products domain. However, until today, no attempt to analyze the structural diversity of various spirocyclic motifs occurring in natural products and their relative populations with unique compounds reported in the literature has been undertaken. This review aims to fill that void and analyze the diversity of structurally unique natural products containing spirocyclic moieties of various sizes.
\end{abstract}

Keywords: natural products; spirocycles; chemical diversity; biological activity; privileged structures

\section{Introduction}

Natural products play the central role in drug discovery [1] due to their inherent biological activity and because have a wide span of structural diversity. Spirocyclic compounds have also occupied a special place in medicinal chemistry [2]. Spirocycles are thought to possess a good balance of conformational rigidity and flexibility to be, on one hand, free from absorption and permeability issues characteristic of conformationally more flexible, linear scaffolds. On the other hand, spirocycles are more conformationally flexible compared to, for example, flat aromatic heterocycles and can adapt to many proteins as biological targets; thus, increasing the chances of finding bioactive hits [3]. Spirocycles are distinctly three-dimensional and initial hits can be further optimized via manipulation of the molecular periphery whose three-dimensional positioning is well defined [4]. We thought it worthwhile to gain insight into the structural diversity of naturally-occurring spirocyclic compounds in relation to the information of their biological activity which would provide a new angle for designing novel bioactive, druglike compounds. Modern literature features a limited number of reviews devoted to total syntheses of spirocyclic natural products [5], including one for spirolactones [6] and one for spirooxyindoles [7]. Illustrative examples of approved natural-product drugs containing a spirocyclic motif include antifungal drug griseofulvin (1) and diuretic drug spironolactone (2). Interesting related compounds that have not achieved clinical approval include isochromanquinone antibiotic griseusin $\mathrm{B}$ (3) $[8,9]$ and spirotriprostatin (4) [10] (Figure 1).

For the purpose of the analysis presented in this review, we considered the chemical diversity of structurally unique and well characterized (i.e., those whose structures were assigned using modern analytical techniques) spirocyclic compounds registered in the ChemBL or SciFinder databases, or the Dictionary of Natural Products (DNP). The occurrence of various ring combinations (A = any atom, mostly carbon or oxygen) selected for discussion in this review is presented in Table 1. 
<smiles>COC1=CC(=O)[C@]2(Oc3c(Cl)c(OC)cc(OC)c3[C@H]2C)C(C)C1</smiles>

1<smiles>Cc1cccc2c1C(=O)C1=C(C[C@H](CC(=O)O)O[C@]13CCCCO3)C2=O</smiles>

3
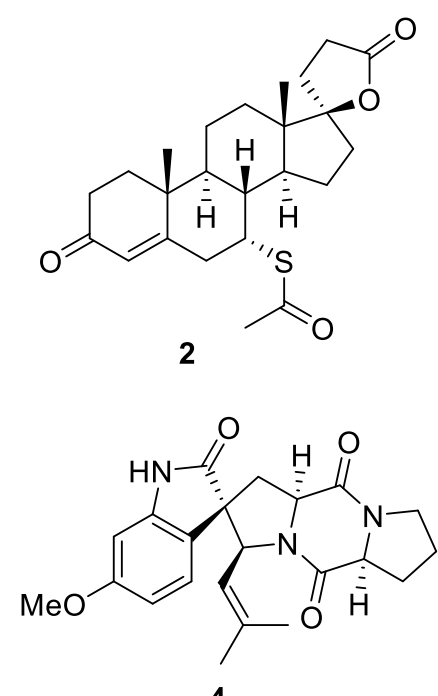

4

Figure 1. Examples of pharmaceutically important compounds bearing a spirocyclic motif.

Table 1. Occurrence of various ring combinations in the spirocyclic natural products analyzed in this review.

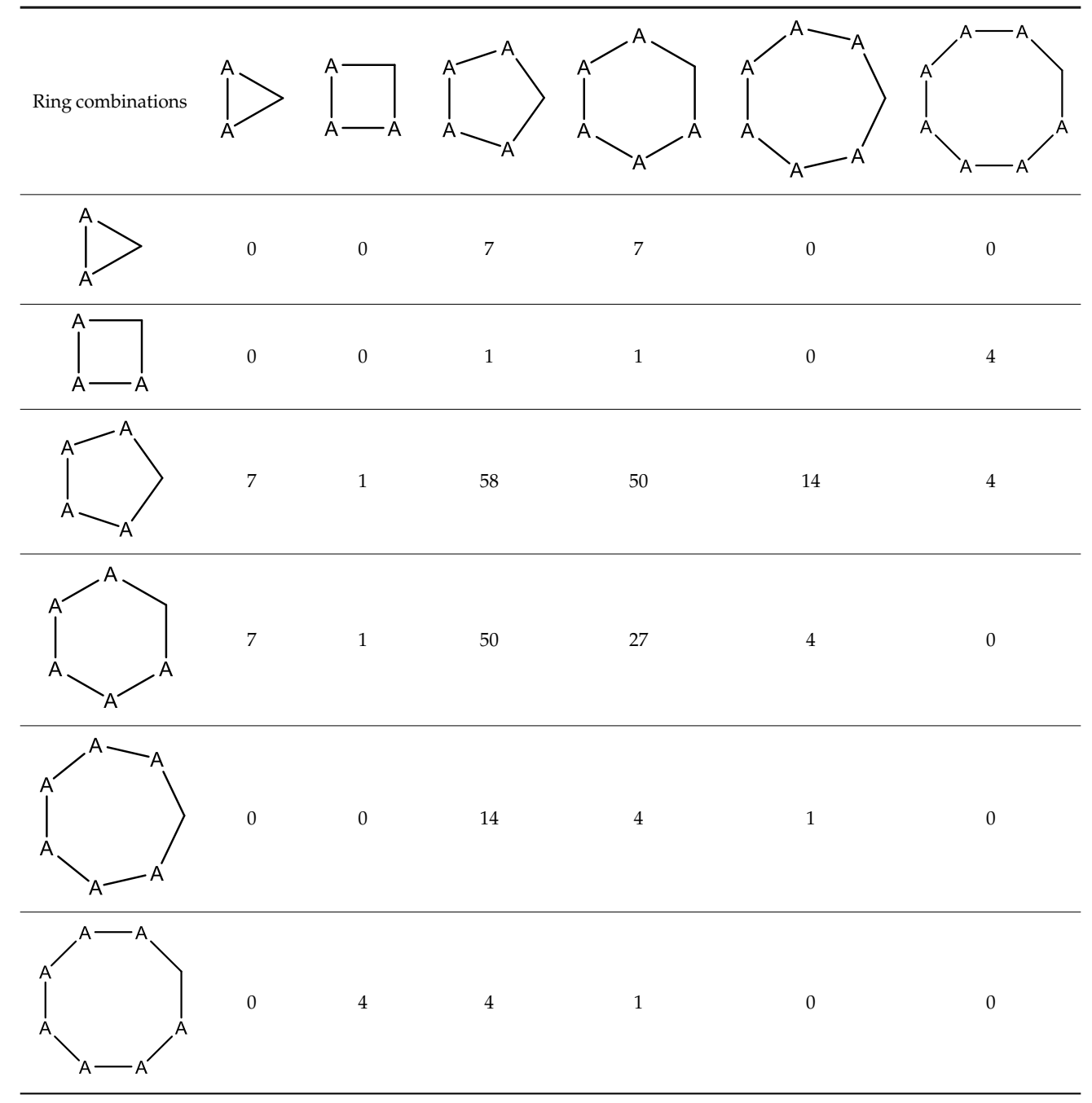


Considering the uneven distribution of the ring combination occurrence statistics (Table 1), the present review is structured according to the size of the [x.y.0] spirocyclic system. The review aims to cover either rare representatives of the spirocyclic systems that seldom occur in the natural product realm or only structurally-unique, representative compounds for those spirocyclic systems that are more widely populated with natural products reported in the literature, with an emphasis on their associated biological activities and the solid structure assignment techniques employed (structures assigned solely based on mass-spectrometric measurements are not taken into account).

\section{2. [2.4.0] Spirocyclic System}

Spirocyclic motifs containing a cyclopropane unit were found in some sesquiterpenes (5-7) which were isolated from the essential oils of South-American Schinus terebinthifolius fruit [11] (Figure 2).

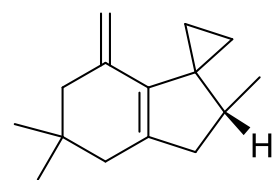

5

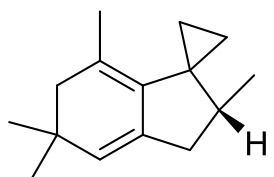

6

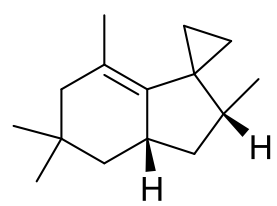

7

Figure 2. Sesquiterpenes from Schinus terebinthifolius fruit containing a [2.4.0] spirocyclic moiety.

In 2017, a novel condensed [2.4.0] spirocycle (8) was reported [12]. It was isolated and characterized among the secondary metabolites of the Helminthosporium velutinum plant and was named cyclohelminthol $\mathrm{X}$ (Figure 3). This compound was shown to inhibit the growth of a human colon adenocarcinoma (COLO201) cell line with moderate potency $\left(\mathrm{IC}_{50}=16 \mu \mathrm{M}\right)$, and, much more potently $(\mathrm{IC} 50=0.35 \mu \mathrm{M})$-leukemia HL60 cell line [12].

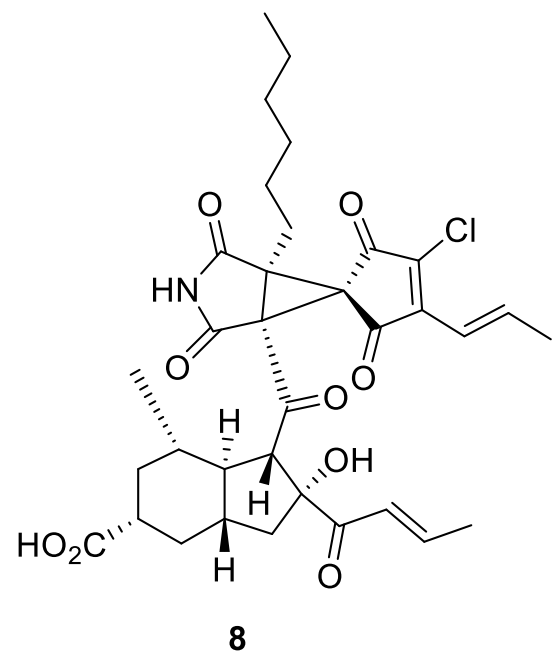

Figure 3. Cyclohelminthol X (8) from Helminthosporium velutinum plant.

Bioassay-guided separation of Valerianae Radix plant extract led to the isolation and characterization of valtrate (9), which inhibited Rev protein mediated transport of HIV-1 from the nucleus to cytoplasm (Figure 4). This compound also inhibited p-24 production of HIV-1 virus without any notable cytotoxicity displayed against MT-4 cells. The presence of the chemically labile oxirane ring as part of the generalized [2.4.0] spirocyclic system is likely critical for the observed inhibition, as 9 was shown to covalently interact with cysteine [13].

Additional two compounds (31 and 32) containing this and another ([4.4.0]) spirocyclic system are discussed in Section 7 of this review. 


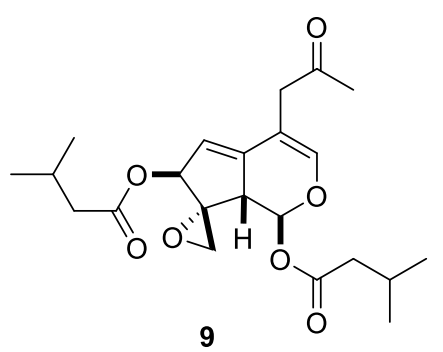

Figure 4. Valtrate (9) isolated from Valerianae Radix plant extract inhibiting HIV-1 transport.

\section{3. [2.5.0] Spirocyclic System}

This group of spirocyclic natural products is represented by sesquiterpenoids illudins $\mathrm{M}$ and $\mathrm{S}$ (10 and 11, respectively) isolated from fungi, including the highly poisonous Jack-o'-lantern mushroom Omphalotus illudens. Compound $\mathbf{1 1}$ is currently in Phase II clinical trials against ovarian, prostate, and gastrointestinal cancers (Figure 5).<smiles>CC1=C2C(=O)C(C)(C)C3(CC3)C(=O)C2=CC1(C)C</smiles>

10<smiles>CC1=C2C(=C[C@@](C)(CO)[C@@H]2O)C(=O)C(C)(C)C12CC2</smiles>

11

Figure 5. Structures of fungi-derived illudins $M$ and $S$.

Structurally analogous to illudins are sesquiterpenes 12-14 isolated from fungus Agrocybe aegerita [14] also containing a [2.5.0] spirocyclic system (Figure 6). These compounds displayed antifungal activity against Candida albicans and Candida kefyr.<smiles></smiles>

12<smiles>CC1(C)C=C2C=C(CO)C3(CC3)C(C)(O)C2C1</smiles>

13<smiles>C=C1CC2C(=C(CO)C13CC3)CC(C)(C)C2O</smiles>

14

Figure 6. Structures of sesquiterpenes 12-14 isolated from fungus Agrocybe aegerita.

An oxirane-bearing sesquiterpene (-)-ovalicin (15) also containing a [2.5.0] spirocyclic system was isolated from fungus Pseudorotium ovalis Stolk [15]. It-and the structurally similar monoester fumagillin (16) displayed potent antiparasitic activities and are generally devoid of toxicity [16] (Figure 7). For both compounds 15 and 16, total syntheses have been reported [17].<smiles>CO[C@H]1C(=O)CC[C@@](C)(O)[C@@]1(O)[C@H]1O[C@@]1(C)CC=C(C)C</smiles>
15

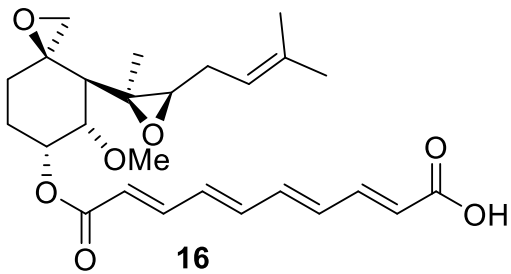

16

Figure 7. Structures of antiparasitic, fungus-derived (-)-ovalicin (15) and fumagillin (16).

A [2.5.0] spirocyclic system is recognizable in the structure of duocarmycin SA (17) and duocarmycin A (18) — new antitumor antibiotics isolated from streptomyces sp. (Figure 8) [18]. 
<smiles>COC(=O)c1cc2c([nH]1)C(=O)C=C1N(C(=O)c3cc4cc(OC)c(OC)c(OC)c4[nH]3)CC3CC123</smiles>

Figure 8. Structures of duocarmycin antitumor antibiotics.

\section{4. [3.4.0] Spirocyclic System}

This is an exceedingly rare type of spirocyclic motif encountered among natural products. The only compound reported in the literature to date containing such a spirocyclic system presented as a combination of a $\beta$-lactone and a pyrrolidine ring (19) was isolated from marine-derived Streptomyces strain collected in the southern area of the Korean Jeju Island [19] (Figure 9). This structurally intriguing compound displayed antibacterial activity.

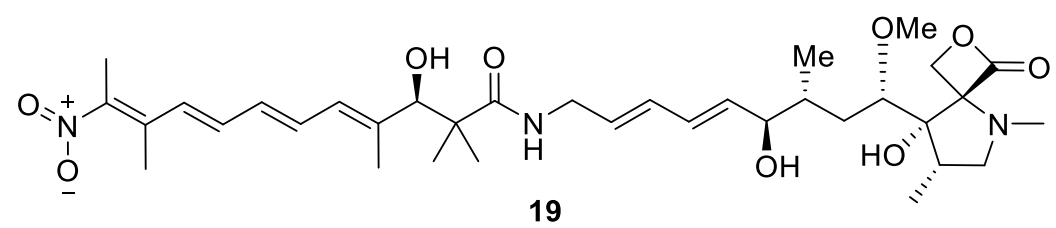

Figure 9. The only known natural product containing a [3.4.0] spirocyclic motif.

\section{5. [3.5.0] Spirocyclic System}

The only spirocyclic combination of a four and six-membered rings represented in natural products is rather simple achiral 1-oxaspiro[3.5]nonan-7-ol substituted cleroindicin A (20) [20]. This compound was isolated from fungus Clerodendrum japonicum (Figure 10).<smiles>OC1CCC2(CCO2)CC1</smiles>

20

Figure 10. Cleroindicin A isolated from fungus Clerodendrum japonicum.

\section{6. [3.7.0] Spirocyclic System}

This intriguing spirocyclic combination of four and eight-membered rings is represented in only four closely-related sesquiterpene bis-lactones, 21-24 (Figure 11), isolated from poisonous plants in the Illicium genus grown in China [21]. These structures could also be viewed as possessing a [3.5.0] spirocyclic motif.

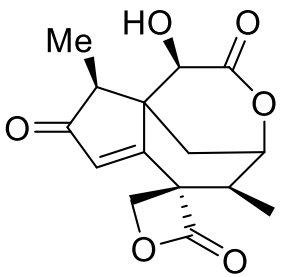

21

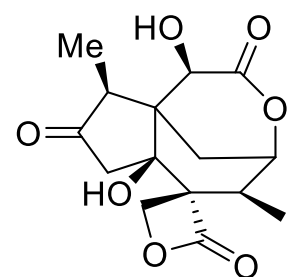

22

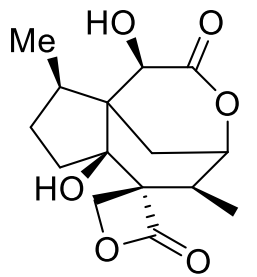

23

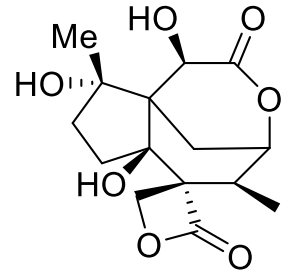

24

Figure 11. Sesquiterpene bis-lactones isolated from Illicium plants containing a [3.7.0] spirocyclic motif. 


\section{7. [4.4.0] Spirocyclic System}

Besides the approved diuretic spironolactone (2, vide supra), heteroatom-containing [4.4.0] spirocyclic motifs are widely represented by various lactones (Figure 12).

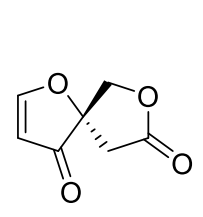

25<smiles>C=C[C@]1(C)COC(=O)[C@]12OC([C@H](C)CC)=CC2=O</smiles>

26<smiles>C=C[C@]1(C)COC(=O)[C@]12OC(c1ccccc1)=CC2=O</smiles>

27

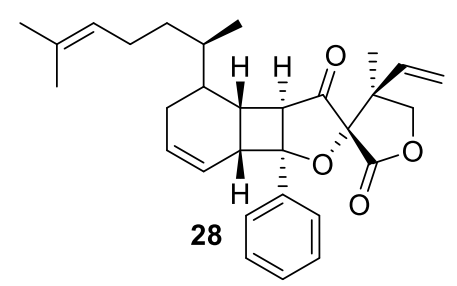<smiles>O=C1C=C[C@]2(C[C@@H](O)[C@@H](c3ccccc3)O2)O1</smiles>

29<smiles>C[C@@H]1O[C@@H]2C[C@@]3(C=CC(=O)O3)O[C@H]2[C@@H]1O</smiles>

30

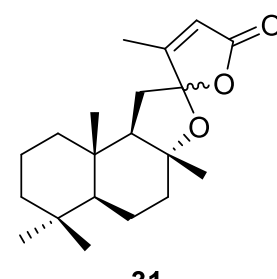

31

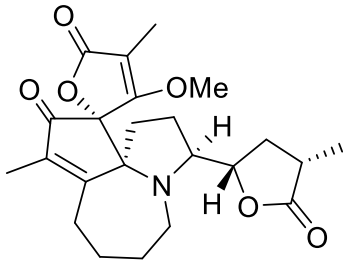

32

Figure 12. Various naturally occurring [4.4.0] spirocyclic lactones.

The most structurally simple, naturally occurring spirocyclic lactone, 1,7-dioxaspiro[4.4.0]nonane or longianone (25) was isolated from higher fungi Xylaria longiana [22]. The absolute configuration of longianone was confirmed by stereoselective total synthesis [23]. Hyperolactones A (26) and C (27) isolated from Hypericum chainens plant [24] displayed antiviral activity [25]. The Nicolaou group reported a photochemical, [2 + 2]-cycloaddition based synthesis of a library based on natural product biyouyanagin (28) which allowed revising its originally reported absolute configuration [26]. (+)-Crassalactone D (29) is a styryl-lactone isolated from the leaves of Polyalthia crassa plant which displayed cytotoxic properties [27]. Pyrenolide D (30) is a highly oxygenated tricyclic spirolactone isolated from phytopathogenic fungus Pyrenophora teres, also displaying potent cytotoxicity [28]. Sesequiterpene levantenolide (31) also contained a [4.4.0] spirocyclic lactone moiety; it was isolated from tobacco grown in Turkey [29]. It exerted potent suppression of cytokine cascades and can, therefore, be considered a lead for anti-inflammatory drug development [30]. Complex polycyclic alkaloids represented by compound 32 were isolated from Stemona genus shrubs. These compounds contain a basic cyclopenta[1,2-b]pyrrolo[1,2-a]azepine scaffold and display promising anti-cough medicinal properties [31] (Figure 12).

A [4.4.0] spirocyclic lactone moiety is found (in combination with a [2.4.0] spirocyclic oxirane) in limonoids 33-34, which were recently isolated from Trichilia connaroides (Figure 13). For these compounds, some insights into a possible biosynthetic pathway have been provided. Likewise, these compounds were screened for various types of bioactivity and have been shown to inhibit NO production in a cellular model of inflammation (induced in RAW264.7 cell line with LPS) by $25.89 \%$ and $37.13 \%$ at 25 and $50 \mu \mathrm{M}$, respectively [32].

Studies of secondary metabolite structures in endophyte fungus Penicillium purpurogenum unveiled a series of unique sesquiterpene lactone compounds (35-37) containing spirocyclic combinations of three five-membered rings (Figure 14). All three compounds were screened against several cancer cell lines (melanoma M14, colon cancer HCT-116, glioma U87, ovary cancer A2780, stomach cancer BG-823, hepatoma Bel-7402, and lung cancer A549) and several pathogenic microorganisms (Mycobacterium spegmatis (ATCC70084), Staphylococcus aureus (ATCC25923), and Staphylococcus epidermidis (ATC12228)); however, no activity was detected at $50 \mu \mathrm{M}$ [33].

Rather intriguing are the structures of curcumanolides 38-41, natural [4.4.0] spirocyclic lactones recently isolated from Curcuma heyneana, a traditional medicinal plant of Indonesia (Figure 15) [34]. 


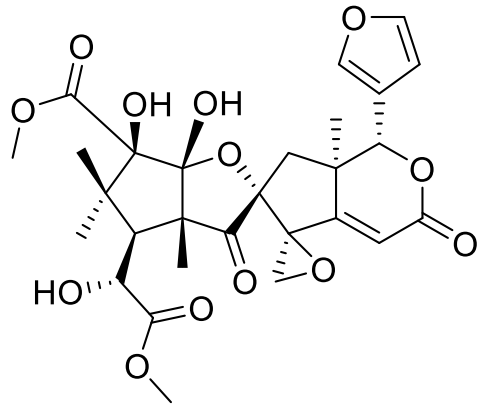

33<smiles>COC(=O)[C@H](O)[C@@H]1[C@@]2(O)C[C@@]3(O[C@]4(O)C(=CC(=O)O[C@H]4c4ccoc4)[C@@]4(CO4)C(=O)C3(C)C)C(=O)[C@]12C</smiles>

34

Figure 13. Limonoids 31-32 containing both a [4.4.0] and a [2.4.0] spirocyclic system.<smiles>CC(=O)OCC[C@H]1CC=C(C)C12CO[C@@]1(OC(=O)[C@@]3(C)O[C@@H]31)[C@H]2O</smiles>

35<smiles>COC1O[C@@]2(OC(=O)[C@@]3(C)O[C@@H]32)[C@H](O)C12C[C@H]1C=CC[C@H]2C1</smiles>

36

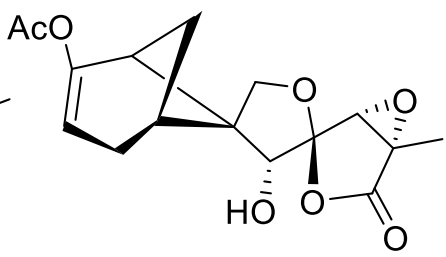

37

Figure 14. Tricyclic spirolactones (incorporating two [4.4.0] spirocyclic systems) isolated from Penicillium purpurogenum.

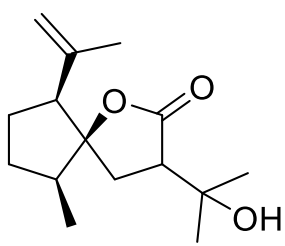

38

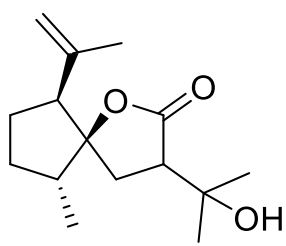

39

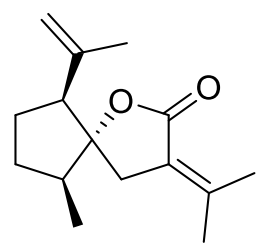

40

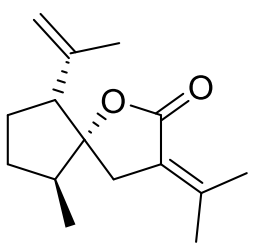

41

Figure 15. New spirocyclic curcumanolides possessing a [4.4.0] spirocyclic system each, isolated from Curcuma heyneana.

In the course of the thorough structural investigation of a series of iridoid glycosides isolated from the Morinda citrifolia plant, a revised structure was assigned. In particular, dehydromethoxygaertneroside (42), dehydroepoxymethoxygaertnoside (43), and citrifolinoside A (44) were shown to be structurally distinct compounds, all of which, however, possessed a [4.4.0] spirocyclic lactone moiety (Figure 16) [35].<smiles>COC(=O)C1=CO[C@H](O[C@@H]2O[C@H](C)[C@@H](O)[C@H](O)[C@H]2O)[C@@]2(C)[C@@H]1C=C[C@]21C=C(C(=O)c2ccc(O)c(OC)c2)C(=O)O1</smiles>

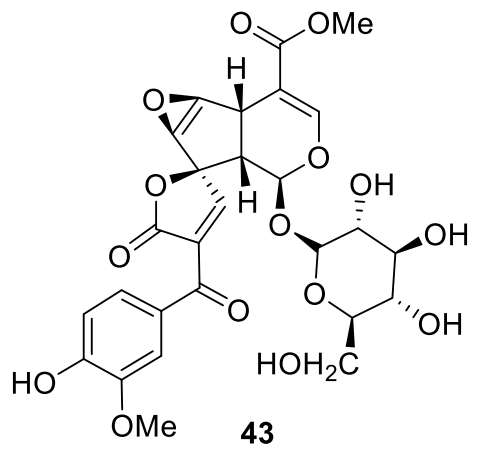

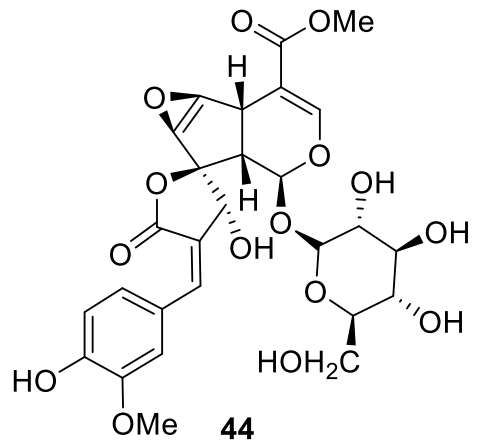

Figure 16. New iridoid glycosides isolated from Morinda citrifolia plant. 
Two diastereomers of spirophthalides, 45 and 46, which possess a unique presentation of a [4.4.0] spirocyclic lactone, were recently isolated from a marine-sponge-derived fungus, Setosphaeria sp. (Figure 17) [36].<smiles>CCC[C@H]1C[C@@H](O)[C@]2(OC(=O)c3c2cc(OC)c(OC)c3O)O1</smiles><smiles>CCC[C@H]1C[C@@H](O)[C@]2(OC(=O)c3c2cc(OC)c(OC)c3O)O1</smiles>

Figure 17. Diastereomeric spirophthalides recently isolated from marine-sponge-derived fungus Setosphaeria sp.

Unique spirocyclic dihydroindole-containing [4.4.0] spirocyclic lactones 47 and 48 , also possessing a quinazolone substituent, were identified among mycotoxins produced by P. aethiopicum (Figure 18) [37].<smiles>CC(=O)O[C@H](C)c1nc2ccccc2c(=O)n1[C@@H]1C[C@@]2(OC1=O)c1ccccc1N1C(=O)C(C)(C)N(O)[C@H]12</smiles><smiles>[CH]C(=O)O[C@H](c1nc2ccccc2c(=O)n1[C@H]1C[C@@]2(OC1=O)c1ccccc1N1C(=O)C(C)(C)N(O)[C@H]12)C(C)C</smiles>

Figure 18. Spirocyclic mycotoxins produced by P. aethiopicum.

During a chemical and structural investigation of secondary metabolites of Penicillium dangeardii, a series of related [4.4.0] spirocyclic lactones (penicillactones A-C) 49-51 was identified. These possessed a complex molecular framework rich in carboxylate functionality and a well stereodefined substitution pattern around the spirocyclic core (Figure 19). Compounds 49-51 showed promise as leads for new antibiotic development. Additionally, penicillactones B and C (50 and 52, respectively) showed inhibition of the release of $\beta$-glucuronidase from polymorphonuclear leukocytes with $\mathrm{ED}_{50}$ values of 2.58 and $1.57 \mu \mathrm{M}[38]$.
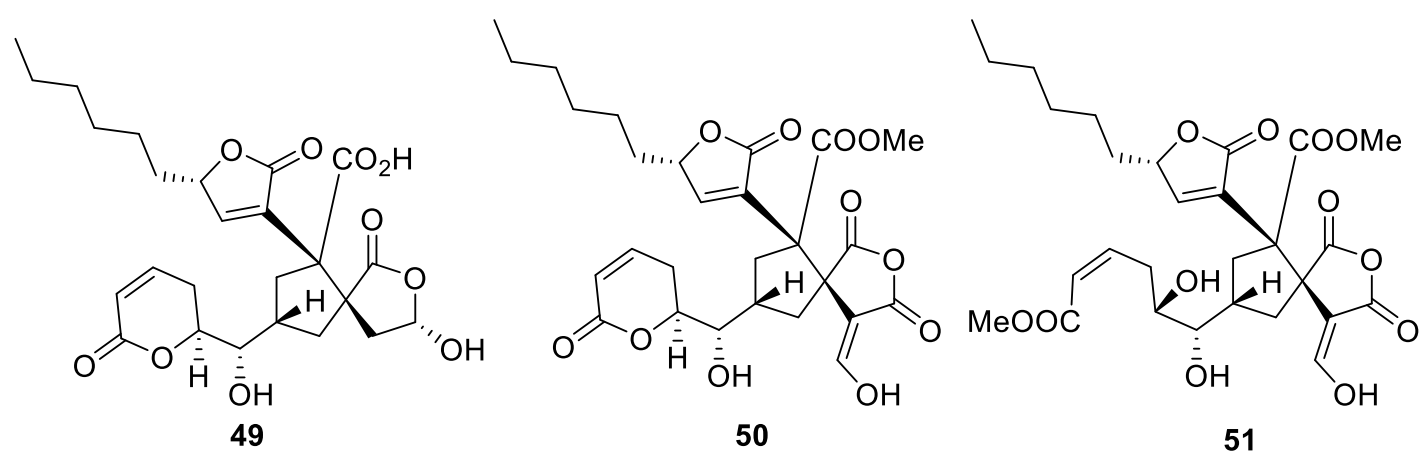

Figure 19. Spirocyclic lcatones isolated from Penicillium dangeardii. 
Rather intriguing and unique is the structure of spirocyclic hydantoins possessing a furanose unit. One of the first representatives of these natural products (hydantocidine 52) was isolated from Streptomyces hygroscopicus (Figure 20). Hydantocidine displayed herbicidal properties which were linked to its ability to inhibit adenylate succinate synthase [39].<smiles>O=C1N[C@H](O)[C@]2(N1)C(=O)NC(=O)[C@@H]2O</smiles>

Figure 20. Structure of herbicidal hydantocidine isolated from Streptomyces hygroscopicus.

A unique presentation of a [4.4.0] spirocyclic system is featured in spirocyclic benzofuranones 53-55 isolated from ethanolic extracts of Ganoderma Applanatum (Figure 21) [40].<smiles>C=C(CO)[C@H]1CC[C@@H](C)[C@]12Oc1ccc(O)cc1C2=O</smiles><smiles>COC(=O)[C@H]1CC[C@@H](O)[C@]12Oc1ccc(O)cc1C2=O</smiles><smiles>C[C@@H](CO)[C@H]1CC[C@@H](C)[C@]12Oc1ccc(O)cc1C2=O</smiles>

55

Figure 21. Spirocyclic benzofuranones isolated from Ganoderma Applanatum.

Not less interesting than the spirocyclic benzofuranones discussed above are natural products possessing a spirooxyindole motif. One of the first representatives of [4.4.0] spirocyclic compounds reported in the literature is spirotriprostatine (56), possessing moderate $\left(\mathrm{IC}_{50}=197.5 \mu \mathrm{M}\right)$ cytotoxic activity [41]. Naturally occurring spirooxyindoles were first isolated from plants Apocynaceae and Rubiacae, and from Aspidosperma, Mitragyna, Ourouparia, Rauwolfia and Vinca genera. These compounds can be further classified into two substructural classes: the tetracyclic secoyohimbane type (e.g., rhynchophylline (57)) and the pentacyclic heteroyohimbane type (e.g., formosanine (58)) (Figure 22) [42].<smiles>COc1ccc2c(c1)NC(=O)C21CC2C(=O)N3CCC[C@H]3C(=O)N2C1C=C(C)C</smiles>

56<smiles>COc1ccc2c(c1)C1(CCN(C)C1)C(=O)N2</smiles>

57<smiles>C=C[C@H]1CN2CC[C@@]3(C(=O)Nc4cc(O)ccc43)[C@@H]2CC1CC1NCCc2c1[nH]c1ccccc21</smiles>

58

Figure 22. Examples of naturally occurring spirooxyindoles.

A very interesting class of natural products containing a [4.4.0] spirocyclic motif includes spiropseudoindoxyl alkaloids. Microbial transformation of the alkaloid mitragynine by the fungus Helminthosporum sp. was reported in 1974 to yield two major metabolites. The compounds were isolated from the biological milieu and their structures were elucidated as mitragynine pseudoindoxyl (59) and hydroxy mitragynine pseudoindoxyl (60) (Figure 23) [43]. These compounds were later shown to possess opioid analgesic activity by exerting mu agonism and delta antagonism while not recruiting $\beta$-arrestin-2 [44]. 


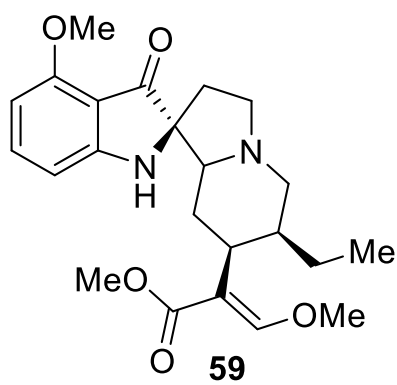<smiles>CCC1CN2CC[C@]3(Nc4cccc(OC)c4C3=O)C2CC1/C(=C\OC)C(=O)OC</smiles>

Figure 23. Structures of mitragynine pseudoindoxyl (59) and hydroxy mitragynine pseudoindoxyl (60).

The [4.4.0] spirocyclic pseudoindoxyl motif represents a rather common feature in indole alkaloids, as can be illustrated by such examples as fluorocurine (61) [45], several diketopiperazines isolated from holothurianderived fungus Aspergillus fumigatus (62a-d) [46], brevianamide B (63) [47], and rauniticine pseudoindoxyl (64) [48] (Figure 24).<smiles>C/C=C1/CN2CC[C@@]3(C(=O)c4ccccc4N3[C@@H]2CO)[C@H]1CO</smiles><smiles>COc1ccc2c(c1)N[C@]1(Nc3cc(OC)ccc3[C@@](O)(C(=O)O)[C@H]1O)C2=O</smiles><smiles>CC1=CCCCC1</smiles><smiles>COc1ccc2c(c1)N(C=C(C)C)C(=O)[C@]21[C@@H](O)[C@]2(O)C(=O)N3CCC[C@]3(O)C(=O)N21</smiles><smiles>COc1ccc(CC(C=C(C)C)NC(=O)C2CCCC2)cc1</smiles><smiles>COc1ccc2c(c1)NC(=O)[C@]21C[C@@H]2C(=O)N3CCC[C@H]3C(=O)N2[C@H]1C=C(C)C</smiles>

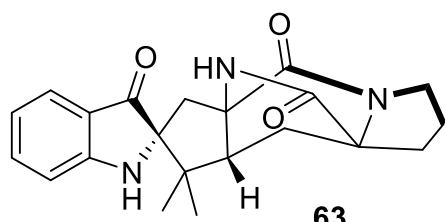<smiles>COC(=O)C1=COC(C(C)C)[C@H]2CN3CC[C@]4(Nc5ccccc5C4=O)C3C[C@H]12</smiles>

Figure 24. Structures of [4.4.0] spirocyclic pseudoindoxyl alkaloids fluorocurine (61), fungus-derived diketopiperazines (62a-d), brevianamide B (63), and rauniticine pseudoindoxyl (64).

A structurally unique [4.4.0] spiroheterocyclic system is represented by a series of highly oxygenated lactone lactams (65-69) isolated from marine sediment-derived fungus Aspergillus sydowi D2-6 (Figure 25). Compounds 65-69 were shown to inhibit growth of adenocarcinoma cell line A549 with an $\mathrm{IC}_{50}$ value of $10 \mu \mathrm{M}$ [49]. 
<smiles>CCc1ccc(C2=C(C)C(=O)[C@@]3(OC(=O)N[C@H]3C(=O)c3ccccc3)[C@H]2O)o1</smiles>

65<smiles>CCc1ccc(C2=C(C)C(=O)[C@]3(NC2=O)OC(=O)[C@H](O)[C@H]3C(=O)c2ccccc2)o1</smiles>

66

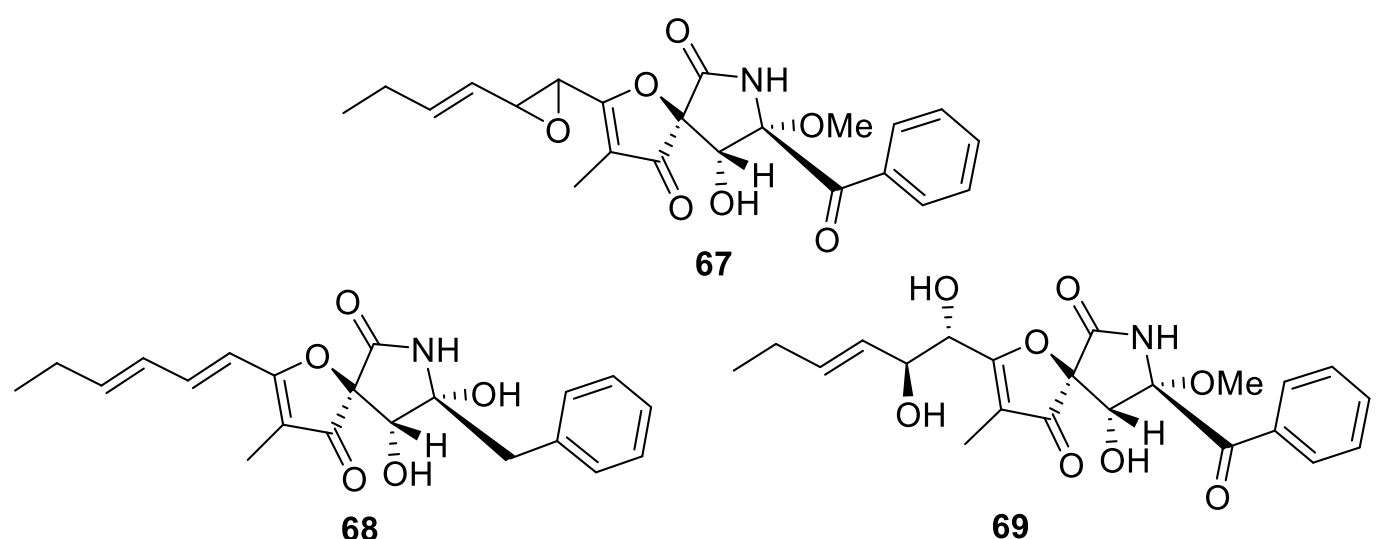

Figure 25. Members of a family of spirocyclic lactone lactams isolated from marine sediment-derived fungus Aspergillus sydowi D2-6.

A wide diversity of heterocyclic spirocyclic scaffolds all belonging to the generalized [4.4.0] system (70-73) (Figure 26) have been isolated recently. Two regioisomeric phytoalexins-erucalexin (70) and its regioisomer (+)-1-methoxyspirobrassinin (71) were isolated from the wild crucifer Erucastrum gallicum [50].<smiles>CSC1=NCC2(Nc3ccccc3C2=O)S1</smiles>

70<smiles>O=C1Nc2ccccc2C12CN=C(SI)S2</smiles>

71<smiles>Cc1nc2ccccc2c(=O)n1C1CC2(OC1=O)c1ccccc1N2O</smiles>

72<smiles>O=C1NC2(CO1)CC(=O)c1ccccc12</smiles>

73

Figure 26. Natural products illustrating the range of heterospirocyclic [4.4.0]-sized motifs.

Mycotoxins related to tryptoquialanine A (71) were isolated from Penicillium spp. and Aspergillus clavatus [51]. For tryptoquialanines, the biosynthetic pathway has been recently elucidated [25]. Another spirooxyindole lactone lactam compound 73 isolated from Coix lachryma-jobi L. has been recently reported and shown to possess activity against human lung cancer (A549) and colon carcinoma (HT-29 and COLO205) cell lines [52].

Secondary metabolite investigation of the liquid culture of entomogenous fungus Isaria cateniannulata led to the identification of a new spirocyclic compound $\mathbf{7 4}$ containing a 1,6-dioxaspiro[4.4]nonane moiety (Figure 27). The compound showed weak inhibitory activity against the HeLa cancer cell line [53].

Spirocyclic [4.4.0] tetrahydrofurans are featured in a series of twelve natural products $75 a-1$ dubbed bipolaricins (Figure 28). These compounds are ophiobolin-type tetracyclic sesterterpenes from a phytopathogenic Bipolaris sp. fungus. They were tested for HMGCoA reductase inhibition as well as anti-inflammatory and cytotoxic activities. The biological activity discovered provided the basis for considering these compounds as leads for antiinflammation and antihyperglycemic therapy developments [54]. 
<smiles>C[C@@H]1CC[C@@]2(C[C@@H](O)[C@@H](CC(=O)O)O2)O1</smiles>

74

Figure 27. 1,6-Dioxaspiro[4.4]nonane secondary metabolite isolated from entomogenous fungus Isaria cateniannulata.
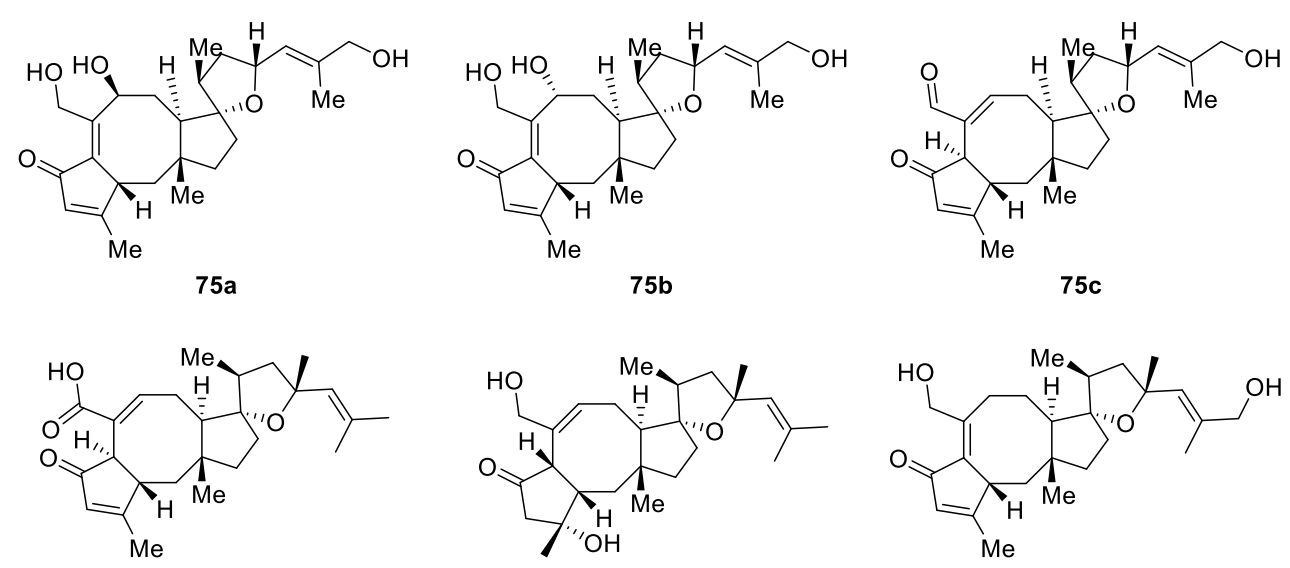

$75 d$

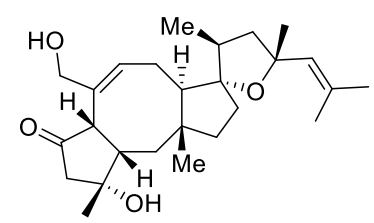

$75 e$

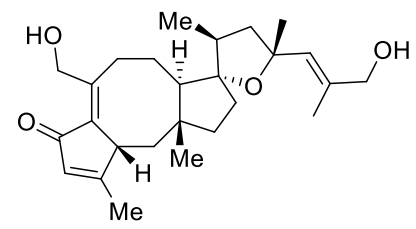

$75 f$
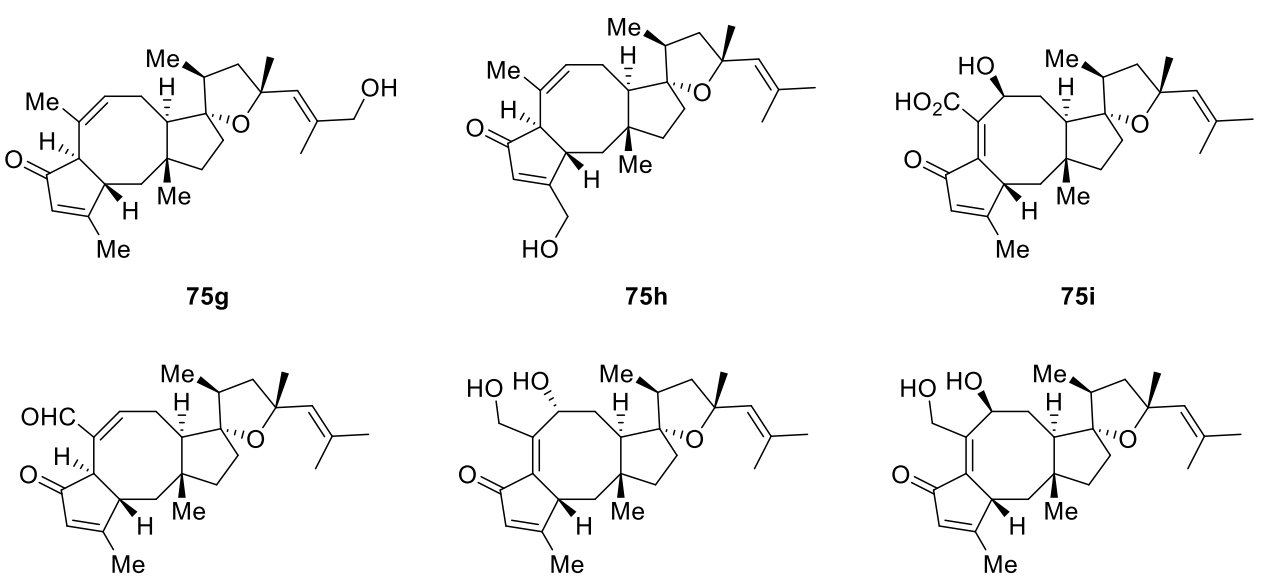

$75 \mathbf{j}$

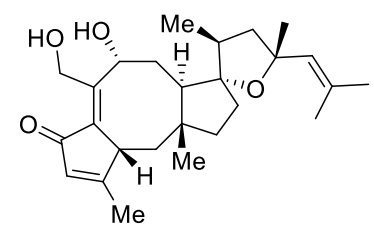

$75 k$

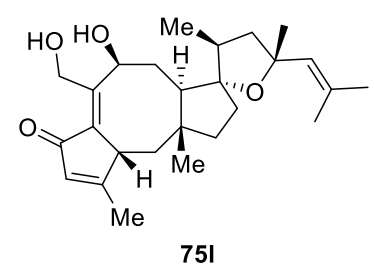

Figure 28. Bipolaricins from phytopathogenic Bipolaris sp. fungus.

An interesting type of [4.4.0] spirocyclic motif is present in fredericamycin A (76), an antitumor antibiotic produced by Streptomyces griseus (Figure 29) [55,56].

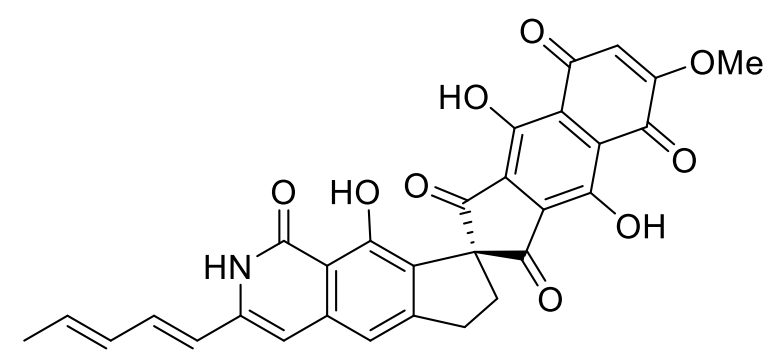

76

Figure 29. Structure of fredericamycin A possessing a [4.4.0] spirocyclic motif. 
Summing up, the overall scaffold distribution within the general [4.4.0] spirocyclic system is shown in Figure 30.

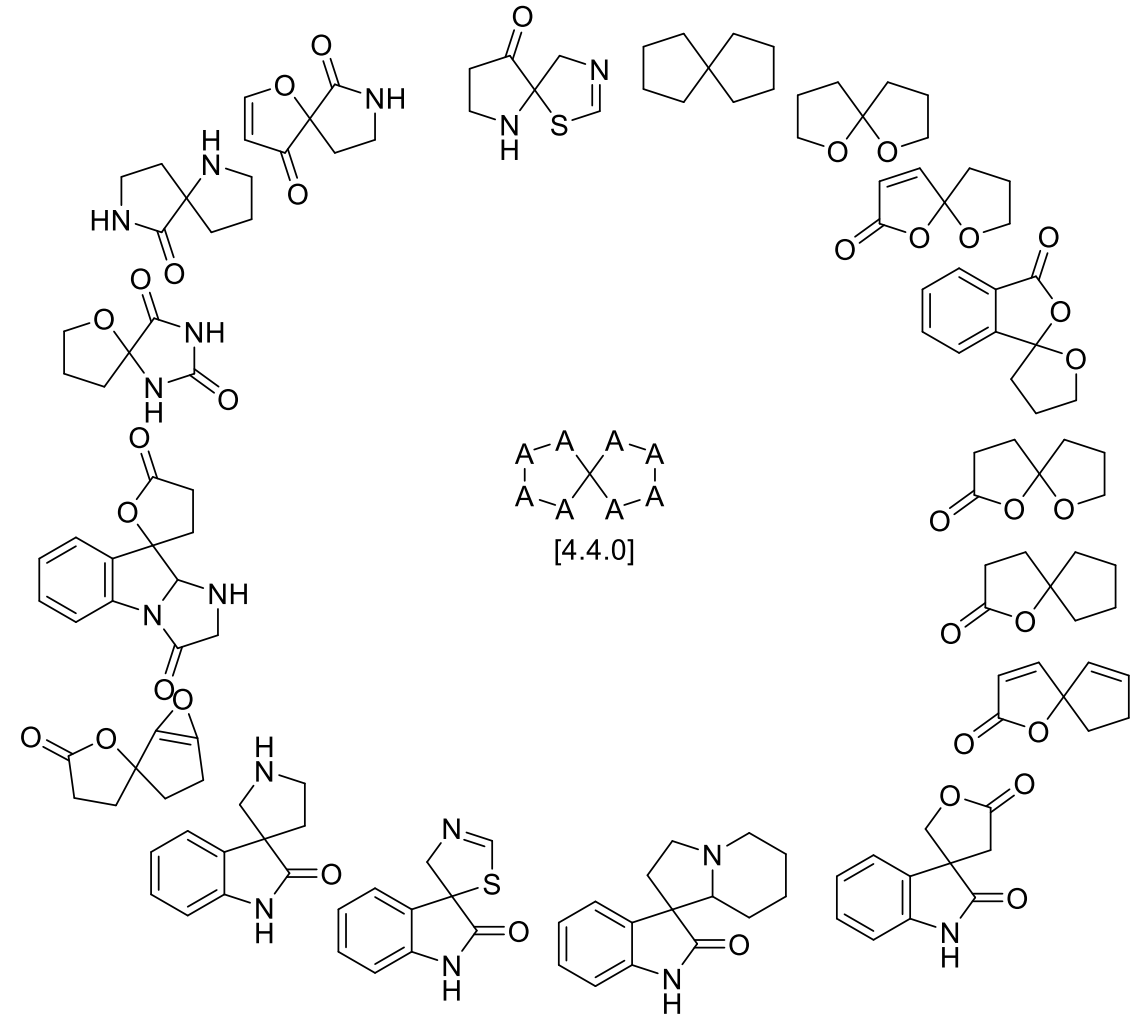

Figure 30. Overall diversity of [4.4.0] spirocyclic scaffolds represented in the natural products domain.

Spirolactones are the most widely represented motifs in the [4.4.0] spirocyclic systems, with over 20 examples discussed above. Spirocyclic lactams are exemplified by 10 natural products. However, [4.4.0] spirocyclic lactam lactones and spirooxyindoles are much less common in the natural products and are represented by only a handful of examples. In terms of biological activity, the current data are mostly limited to cytostatic and antibacterial properties. The natural products isolated within the last 1-2 years are poorly investigated with regard to their biological properties.

\section{8. [4.5.0] Spirocyclic System}

Secondary metabolite investigation of Teucrium viscidum led to the identification of a [4.5.0] spirocyclic compound (77) possessing a unique skeleton [57]. A skeleton of similar complexity had only been featured once in the literature three decades before that [58] (Figure 31).

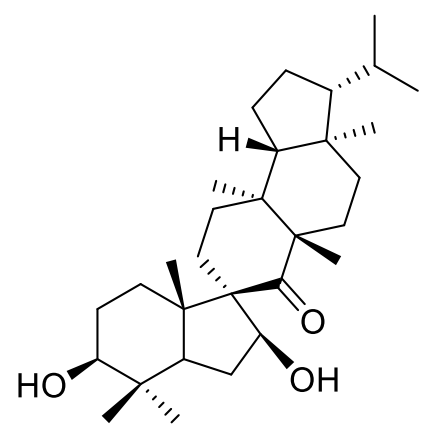

77

Figure 31. Spiro pentacyclic secondary metabolite isolated from Teucrium viscidum. 
The [4.5.0] spirocyclic motifs are featured in many natural terpenes. Recently, new spirocyclic triterpenoids 78-79 were isolated from Leonurus japonicus fruit (Figure 32). These compounds displayed moderately potent $\left(\mathrm{IC}_{50}<10 \mu \mathrm{M}\right)$ growth inhibition of five human cancer cell lines (stomach cancer BGC-823 and KE-97, hepatocarcinoma Huh-7, Jurkat T-cell limphoblasts, and breast adenocarcinoma MCF-7) [59].

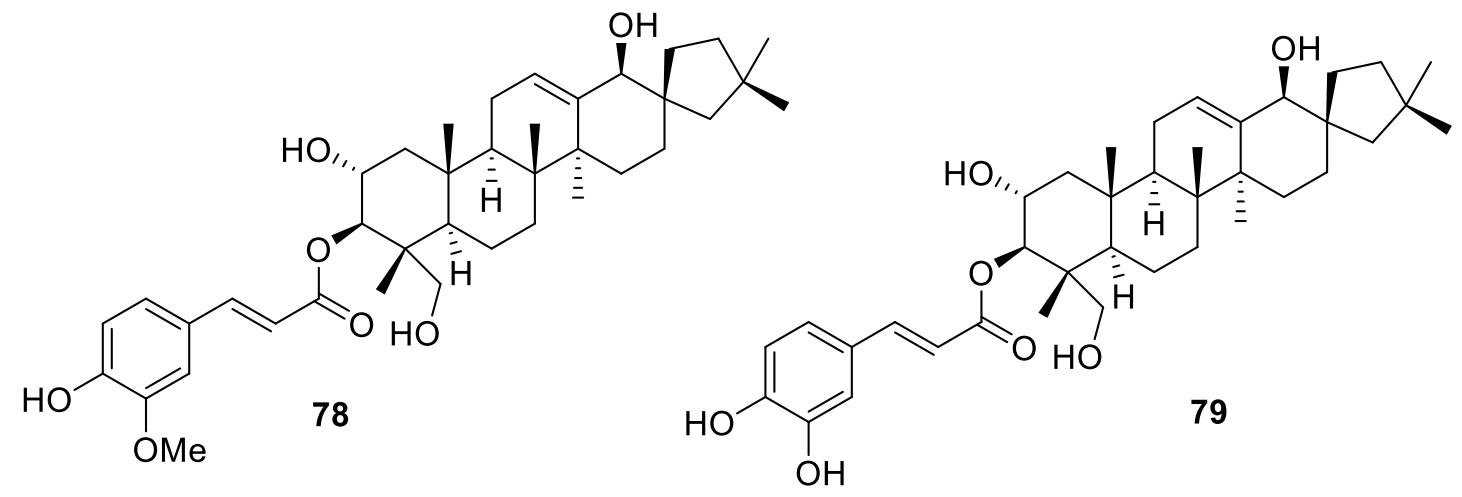

Figure 32. New spirocyclic triterpenoids isolated from Leonurus japonicas.

Another example of an all-carbon [4.5.0] spirocyclic system is provided by spirocarolitone (80), recently isolated from Ruptiliocarpon caracolito [60] (Figure 33).

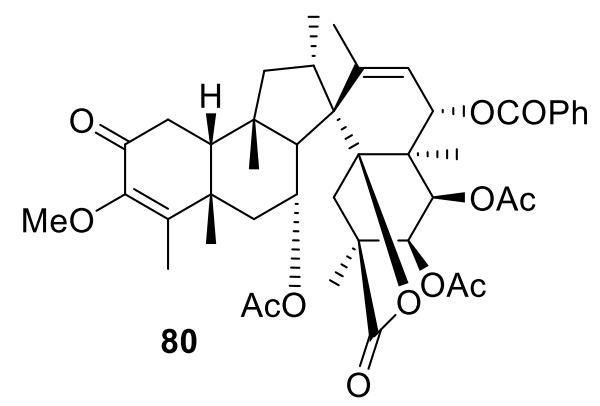

Figure 33. Spirocarolitone isolated from Ruptiliocarpon caracolito.

Structurally novel tricyclic-iridal triterpenoids belamcandanes A and B (81 and 82) (Figure 34) were recently isolated from Belamcanda chinensis and shown to possess moderate hepatoprotective properties. A possible biosynthetic pathway has been proposed [61].

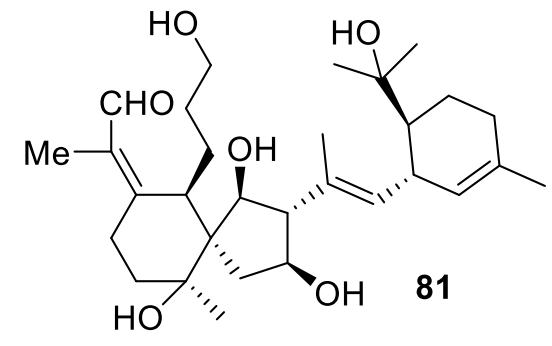

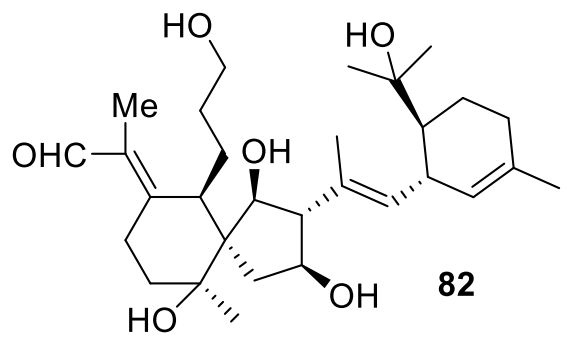

Figure 34. Structurally novel triterpenoids isolated from Belamcanda chinensis.

New biologically active sesquiterpenoids $83-85$ possessing an all-carbon [4.5.0] spirocyclic system were isolated from rhizomes of Acorus calamus (Figure 35). Compound 83 exhibited weak hepatoprotective activities against APAP-induced HepG2 cell damage [62].

The ethyl acetate soluble fraction of a $\mathrm{MeOH}$ extract of the dried stems and roots of Capsicum annum gave several new sesquiterpenoids, among which two [4.5.0] spirocyclic compounds termed canusesnols (86-87, Figure 36) were identified and evaluated for their cytotoxic activities [63]. 


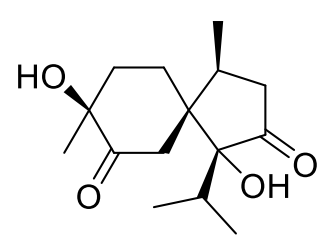

83

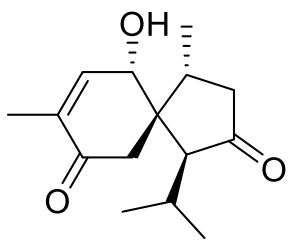

84

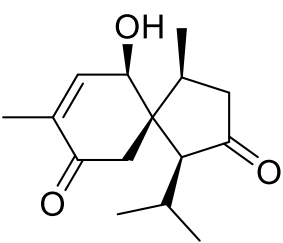

85

Figure 35. The [4.5.0] spirocyclic sesquiterpenoids from rhizomes of Acorus calamus.<smiles>C=C(C)[C@@H]1CC[C@]2(C1)[C@@H](C)C[C@@H](O)C[C@H]2CO</smiles>

86<smiles>C=C(CO)[C@H]1CC[C@]2(C1)C(CO)=CC(=O)C[C@H]2C</smiles>

87

Figure 36. Canusesnols from Capsicum annum.

Perhaps the most clinically advanced natural spirocyclic compound-spirocyclic benzofuran griseofulvin (88) isolated from Penicillium griseofulvum has been employed in clinical practice for therapy against ring worms [64] and was marketed by GlaxoSmithKline under the trade name Grisovin ${ }^{\mathrm{TM}}$ [65] (Figure 37).<smiles>COC1=CC(=O)C[C@H](C)[C@]12Oc1c(Cl)c(OC)cc(OC)c1C2=O</smiles>

88

Figure 37. Anti-ring worm drug griseofulvin (Grisovin ${ }^{\mathrm{TM}}$ ).

Natural [4.5.0] spirocyclic lactones are characterized by a wide structural diversity and abundance of biological activities reported for them. These are exemplified by the mediator of mycoparasitism lambertollol C (89) [66], glycine-gated chloride channel receptor modulator (-)-ircinianin (90) [67], and terpenoid andirolactone (91) isolated from Cedrus libanotica [68] (Figure 38).<smiles>CC1=CC2(CC(=O)c3c(O)cccc3C2=O)OC1=O</smiles>

89<smiles>CC(C)=C[C@H]1C=C(C)[C@H]2CC(C)=C(C)[C@H]2[C@]12OC(=O)C(C)=C2O</smiles>

90<smiles>CC1=CC[C@]2(CC1)OC(=O)C=C2C</smiles>

91

Figure 38. Examples of natural [4.5.0] spirocyclic lactones.

More examples of bioactive [4.5.0] spirocyclic lactones are provided by abyssomicins (92a-c, Figure 39), which were isolated from Actinobacteria and shown to inhibit $p$-aminobenzoate biosynthesis [69].

Antibacterial and antitumor compound lactonamycin Z (93) was isolated from Streptomyces sanglieri [70] and is an example of a [4.5.0] spirocyclic lactone embedded in a complex polycyclic system (Figure 40). 
In 2015, Cech and co-workers reported new antibiotic spirocyclic lactone chaetocuprum (94) [71]. This compound was isolated from an endophyte fungus growing on the roots of wild Anemopsis californica plant which was traditionally used by North American tribes to treat infections and inflammation. Similarly, growing endophyte fungal parasites on the roots of Chaetomium indicum allowed Asai and Oshima [72] to isolate both epimers of spiroindicumide A and B (95 and 96, respectively) which feature an unprecedented spirocyclic lactone scaffold (Figure 41).

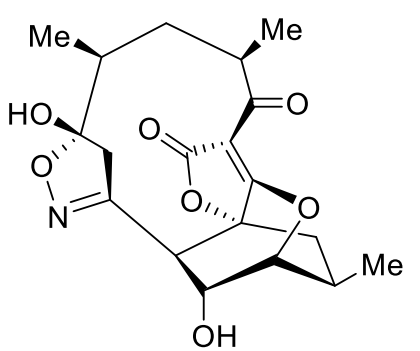

92a

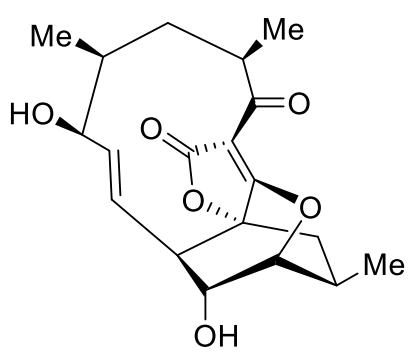

92b

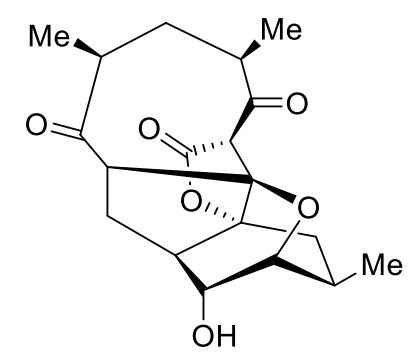

92c

Figure 39. Abyssomycins from Actinobacteria.<smiles>COC1C2(OC3CC(O)C(O)C(C)O3)COC3(OC)CC(=O)OC13C(=O)c1c(cc3cc(O)c4c(c3c1O)CN(C)C4=O)C2=O</smiles>

Figure 40. Antibacterial and antitumor compound lactonamycin Z isolated from Streptomyces sanglieri.<smiles>CC(=CC(=O)O)C(=O)NC1CC2(CC1C(=O)O)OC(=O)C1OC1C1OC12</smiles><smiles>CC(=O)CC1=C(C)C(=O)[C@]2(CC=C(C)C)[C@H](O)[C@@H](O)C(=O)O[C@@]12C</smiles>

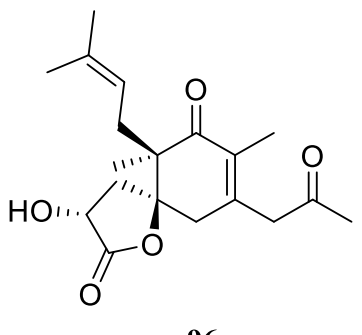

Figure 41. Spirocyclic lactones isolated from endophyte fungal parasites.

In addition to lambertollol $\mathrm{C}$ discussed above, two related epimeric compounds labertollol A (97) and B (98), also bearing a 4,8-dihydroxy-2,3,4-trihydronaphthalen-1-one scaffold and featuring a spirobutenolide moiety (Figure 42) were reported to possess high antifungal activity $\left(\mathrm{IC}_{50}=0.5 \mu \mathrm{g} / \mathrm{mL}\right)[73]$.

Traditional Chinese medicinal plant Rehmannia glutinosa turned out to be a rich source of [4.5.0] spirocyclic lactones: massarigenin D (99), spiromassaritone (100), and paecilospirone (101) (Figure 43) which displayed potent $\left(\mathrm{IC}_{50}\right.$ from 0.25 to $\left.32 \mu \mathrm{g} / \mathrm{mL}\right)$ antifungal activity [74].

Perenniporide A (102) was the only spirocyclic lactone derivative of the naphthalenone family of natural products perenniporides A-D isolated from solid cultures of a fungus Perenniporia sp. inhabiting the larva of Euops chinesis, a phytophagous weevil with high host specificity to the medicinal plant Fallopia japonica (Figure 44) [75]. 
<smiles>CC1=CC2(CC(=O)c3c(O)cccc3[C@@H]2O)OC1=O</smiles><smiles>CC1=C[C@]2(CC(=O)c3c(O)cccc3[C@@H]2O)OC1=O</smiles>

Figure 42. Lambertollols A and B.<smiles>C=C1OC(=O)[C@]2([C@H](C)C=CC(=O)[C@@H]2O)[C@H]1O</smiles>

99<smiles>C=C1OC(=O)[C@]23C[C@H](C)CC(=O)C(O)[C@H]2O[C@H]13</smiles>

100<smiles>C=C1OC(=O)[C@@]2(C(=[W])C=CC(=O)C2O)[C@@H]1CC=CC</smiles>

101

Figure 43. Spirocyclic lactones from traditional Chinese medicinal plant Rehmannia glutinosa.<smiles>CCc1c(OC)cc2c(c1O)C(=O)C=C(OC)C21C[C@@H](C)C(=O)O1</smiles>

102

Figure 44. Perenniporide A, the only spirocyclic lactone of the perenniporide family.

A [4.5.0] spirocyclic lactone moiety is featured in secochiliolide acid 103 (Figure 45), for which antiparasite activity was reported $[76,77]$.

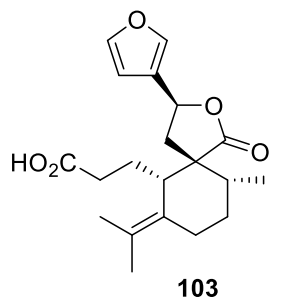

Figure 45. Secochiliolide acid.

A rather unique [4.5.0] spirocyclic lactone moiety was identified in sesquiterpene abiespiroside A (104), which was isolated from Chinese tree Abies dalavayi (Figure 46). For this compound, anti-inflammatory activity was discovered [78].

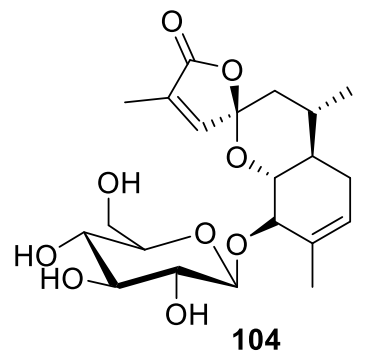

Figure 46. Abiespiroside A isolated from Chinese tree Abies dalavayi. 
A [4.5.0] spirocyclic lactone motif is featured in pathylactone A (105) isolated from marine sources, which demonstrated $\mathrm{Ca}^{2+}$ channel antagonistic activity (Figure 47) [79].

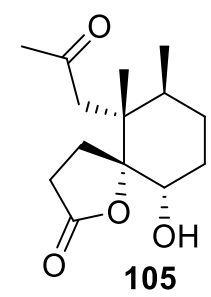

Figure 47. Pathylactone A isolated from marine sources.

A whole series of spirolactones containing a terpenoid carane system (106-110) was reported as synthesized in enantioselective fashion (Figure 48). For these compounds, insect-feeding deterrent activity was reported [80].<smiles>C=C(C)[C@@H]1CC[C@]2(CCC(=O)O2)[C@H](O)C1</smiles>

106<smiles>C=C(C)[C@H]1C=C[C@]2(CCC(=O)O2)CC1</smiles>

107<smiles>CC1(C)CC(=O)O[C@]12CC[C@@H](C)CC2</smiles>

108<smiles>C[C@H]1C=C[C@]2(CC1)OC(=O)CC2(C)C</smiles>

109<smiles>C[C@H]1CC[C@@]2(OC(=O)CC2(C)C)[C@H](O)C1</smiles>

110

Figure 48. Spirocyclic carane lactones with insect-feeding deterrent activity.

In addition to the abundance of [4.5.0] spirocyclic lactones reported in the literature, some instances of spirocyclic tetrahydrofurans can be encountered. For example, 15-methoxycyclocalopin A (111) and isocyclocalopin A (112) were reported to be isolated from Boletus calopus [81]. Notably, compound 112 can be also considered a [5.5.0] spirocyclic hexahydropyran (Figure 49).<smiles>COCC1=CCC2(C(C)O)C(O)C(=O)OCC(C)[C@H]2C(=O)C1O</smiles><smiles>CC1=CCC2(CC1=O)C1OC(C(=O)O)C2OC1C</smiles>

Figure 49. Natural spirocyclic tetrahydrofurans.

The structures of these compounds are reminiscent of spirocyclic dihydrofuran 8,9-dehydrotheaspirone, both enantiomers of which $(\mathbf{1 1 3} \mathbf{a}-\mathbf{b})$ have been reported as volatile constituents of nectarines [82]. Their presence in the fruit was connected to some specific organoleptic properties of some kinds of nectarines (Figure 50)
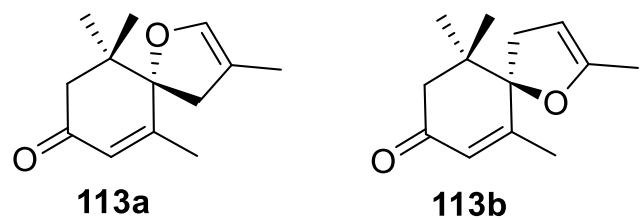

Figure 50. Enantiomers of [4.5.0] spirocyclic dihydrofuran 8,9-dehydrotheaspirone reported in the literature. 
Rather intriguing labdane-type diterpenoids (114a-b), epimeric to each other, isolated from the fruit of Vitex agnus-castus plant feature a unique skeleton consisting of both a [4.4.0] and a [4.5.0] spirocyclic tetrahydrofuran system (Figure 51) [83].

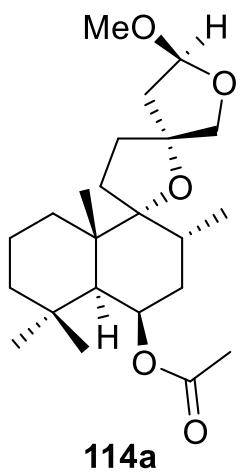

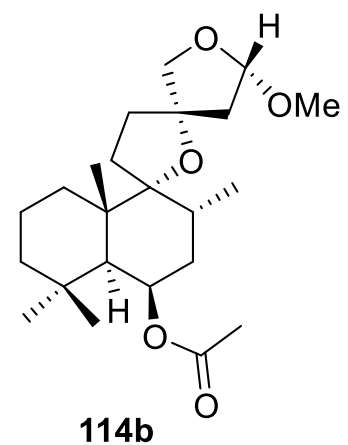

Figure 51. Spirocyclic labdane-type diterpenoids isolated from the fruit of Vitex agnus-castus.

Rather unique is the structure of heliespirone $\mathbf{1 1 5}$ isolated from highly polar fractions of Helianthus annuus L. extract [84]. In this natural product, tetrahydrofuran forms a spirocyclic motif with a quinone-like moiety (Figure 52).<smiles>C=CC1CC(C(C)(C)O)OC12CC(=O)C(C)=CC2=O</smiles>

Figure 52. Spirocyclic natural product heliespirone featuring a tetrahydrofurane and a quinone-like moiety.

An oxygenated [4.5.0] spirocyclic framework is featured in several toxins, exemplified by arthropod toxin 116 (Figure 53) isolated from Dinophysis acuta and shown to potentiate erectile function [85].

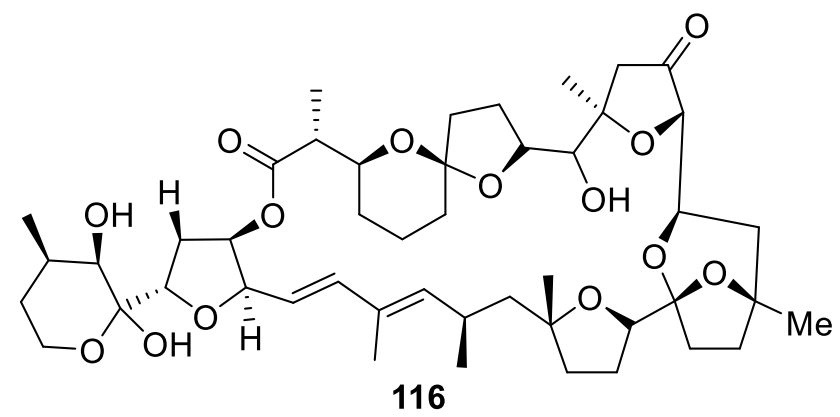

Figure 53. Erectile function-potentiating toxin featuring a [4.5.0] spirocyclic motif.

Another example of similarly polyoxygenated [4.5.0] spirocyclic tetrahydrofuran is provided by quinochalcone 117, named saffloquinoside A, isolated from Carthamus tinctorius (Figure 54) [86]. Compound $\mathbf{1 1 7}$ was evaluated in vitro for the inhibitory effect on the release of $\beta$-glucuronidase from rat polymorphonuclear neutrophils (PMNs) induced by the platelet-activating factor (PAF). It exhibited anti-inflammatory activity and the inhibitory rate was $54.3 \%$ (at $10^{-5} \mathrm{~mol} / \mathrm{L}$ concentration). 


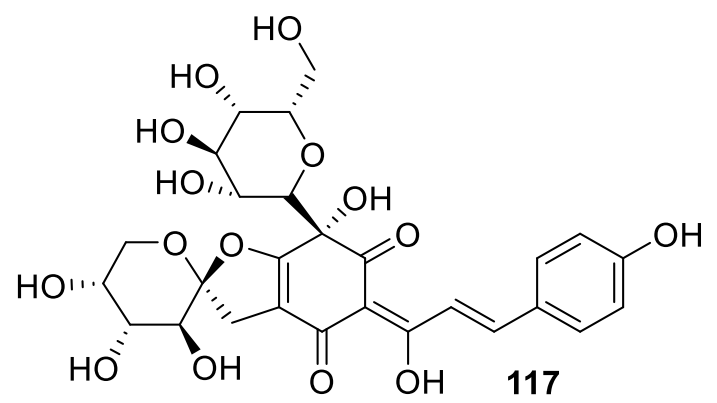

Figure 54. [4.5.0] spirocyclic quinochalcone saffloquinoside A isolated from Carthamus tinctorius.

Nitrogen-containing [4.5.0] spirocyclic systems are a lot more scarce compared to their oxygen-containing counterparts and can be exemplified by only two examples discussed below.

Alkaloid ( \pm )-pandamarine (118) isolated as a major component from Pandanus amaryllif olius contains a [4.5.0] spirocyclic scaffold composed of a piperidine and a pyrollen-2-one rings (Figure 55) [87].

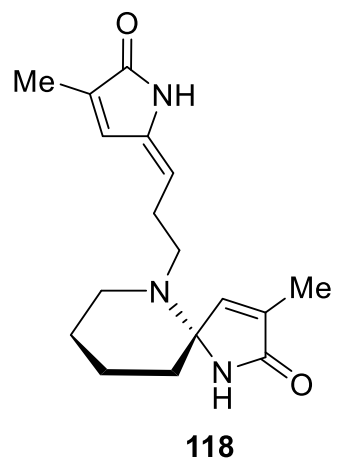

Figure 55. Alkaloid ( \pm )-pandamarine isolated from Pandanus amaryllif olius.

Another example of nitrogen-containing [4.5.0] spirocyclic system is provided by surugatoxin (119) isolated from the toxic Japanese ivory shell (Babylonica japonica) (Figure 56). This toxin suppresses the presynaptic nervous system [88]. Its total synthesis, in the racemic form, was achieved in 1994 by the Inoue group [89].

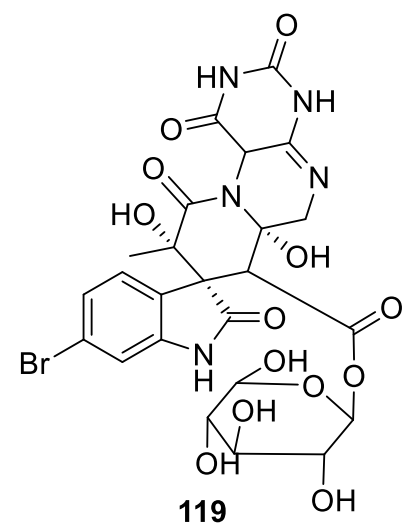

Figure 56. Surugatoxin isolated from the toxic Japanese ivory shell (Babylonica japonica).

A [4.5.0] spirocyclic system is recognizable in spirostaphylotrichins which are spirocyclic $\gamma$-lactams mainly produced by several endophytic fungal strains of Curvularia, Pyrenophora, and Staphylotrichum. These are exemplified by spirostaphylotrichin $X(\mathbf{1 2 0})$, characterized as an antiinfluenza agent targeting RNA polymerase PB2 [90], and spirostaphylotrichin W (121), investigated as a potential mycoherbicide for cheatgrass (Bromus tectorum) biocontrol [91] (Figure 57). 
<smiles>CC/C=C1\C=CC(=O)[C@H](O)[C@]12C(=O)N(OC)C(C)(O)[C@H]2O</smiles>

120<smiles>CCCC1C=CC(=O)[C@@H](O)[C@@]12C(=O)N(OC)C(OC)(OC)[C@H]2O</smiles>

121

Figure 57. Structures of representative spirostaphylotrichins possessing a [4.5.0] spirocyclic motif.

Summarizing this Section, the scaffold diversity stemming from the general [4.5.0] spirocyclic framework is comparable to that of the [4.4.0] spirocyclic system discussed earlier (Figure 30) and is shown in Figure 58.<smiles>O=C1CC2(CCCC3(CCCCO3)O2)CCN1</smiles><smiles>O=C1CC2OCC3CCCCC32O1</smiles>

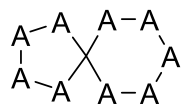

[4.5.0]<smiles>C1CCC2(CC1)CCCC2</smiles><smiles>O=C1c2ccccc2OC12C=CCCC2</smiles><smiles>O=C1C=COC12C=CCCC2</smiles><smiles>O=C1C=CC2(CCCCO2)O1</smiles><smiles>O=C1CCC(O)C2(C1)OC=CC2=O</smiles><smiles>O=C1C=COC12CCCCC2</smiles><smiles>OC1CCOC12CCCCC2</smiles><smiles>C1=CCC2(C1)CCCCC2</smiles>

Figure 58. Current diversity of [4.5.0] spirocyclic scaffolds.

\section{9. [4.6.0] Spirocyclic System}

As to the spirocyclic systems combining five and seven-memebred rings (the [4.6.0] spirocyclic system), spiro meroterpenoids spiroapplanatumines (122-124) isolated from the fruiting bodies of the fungus Ganoderma applanatum provide an eloquent example (Figure 59). Biological evaluation of the compounds disclosed that compound 124 inhibited JAK3 kinase with an $\mathrm{IC}_{50}$ value of $7.0 \pm 3.2 \mu \mathrm{M}$ [92].<smiles>C[C@@H]1CCC=C(C(=O)O)C[C@@]12Oc1ccc(O)cc1C2=O</smiles>

122<smiles>COC(=O)C1=CCC[C@@H](C)[C@]2(C1)Oc1ccc(O)cc1C2=O</smiles>

123<smiles>O=CC1=CCC[C@@H](CO)[C@@]2(C1)Oc1ccc(O)cc1C2=O</smiles>

124

Figure 59. Spiro meroterpenoids spiroapplanatumines (122-124) isolated from fungus Ganoderma applanatum. 
In 2003, investigation of the neutral ether extracts of the fungus Fomes cajanderi led to the isolation of three novel ketal lactones named fomlactones A (125), B (126), and C (127) (Figure 60). The compounds clearly possess a [4.6.0] spirocyclic lactone moiety. However, their biological potential remains to be investigated [93].

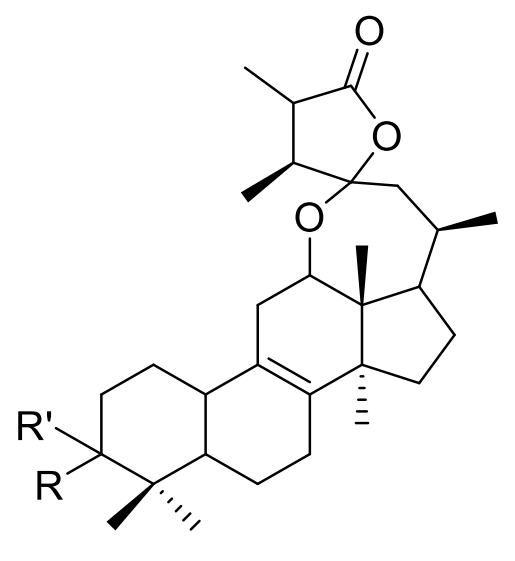

$$
\begin{gathered}
\text { 125, } R=A c O, R^{\prime}=H \\
126, R=O H, R^{\prime}=H \\
127, R=R^{\prime}=O
\end{gathered}
$$

Figure 60. Fomlactones A-C possessing a [4.6.0] spirocyclic moiety.

A very unique spirocyclic [4.6.0] framework formed by a spiro[benzofuranonebenzazepine] skeleton is featured in natural products $( \pm)$-juglanaloid A (128a-b) and ( \pm )-juglanaloid B (129a-b). These benzazepine alkaloids were isolated from the bark of Juglans mandshurica. Remarkably, both racemic natural products were successfully resolved by chiral separation and absolute configurations were unambiguously assigned (Figure 61). These enantiopure versions were screened for their in vitro inhibitory activities against self-induced $A \beta_{1-42}$ aggregation using the Thioflavin $T$ (Th-T) assay using curcumin as a reference compound. The compounds demonstrated promise acting as inhibitors of amyloid $\beta$ aggregation [94].<smiles>COc1cc2c(cc1OC)C(=O)O[C@]1(C2)C(=O)N(C)Cc2cc3c(cc21)OCO3</smiles>

128a<smiles>COc1cc2c(cc1OC)C(=O)O[C@]1(CCN(C)C1=O)C2</smiles>

$128 b$

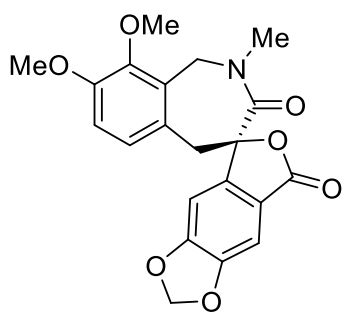

129a<smiles>COc1ccc2c(c1OC)CN(C)C(=O)[C@]1(C2)C(=O)OC(=O)c2cc3c(cc21)OCO3</smiles>

$129 b$

Figure 61. Enantiopure juglanaloid A (128a-b) and juglanaloid B (129a-b) isolated from Juglans mandshurica and further obtained by chiral separation.

Furthermore, in the last 1-2 years there has been an avalanche of new [4.6.0] spirocyclic structures reported in the literature. For examples, lanostane-type spirolactone triterpenoids 130a-c isolated from Ganoderma applanatum (Figure 62) were reported to possess anti-hepatic fibrosis activities [95]. Interestingly, an additional [4.5.0] and [2.5.0] spirocyclic motif is recognizable in compounds $130 \mathrm{~b}$ and 130c, respectively.

Another recent example (reported in 2019) of a [4.6.0] spirocyclic system is provided by grayanane diterpenoid auriculatol A (131) isolated from leaves of Rhododendron auriculatum (Figure 63). This compound is the first example of a 5,20-epoxygrayanane diterpenoid bearing 
a 7-oxabicyclo[4.2.1]nonane motif and a trans/cis/cis/cis-fused 5/5/7/6/5 pentacyclic ring system. Auriculatol A showed analgesic activity in the acetic acid-induced writhing test [96].

Finally another [4.6.0] spirocyclic lactone, seconoriridone A (isolated as a 7:1 epimeric mixture of (132a) and (132b)) was isolated in 2019 from Belamcanda chinensis (Figure 64). Although no biological activity was reported for this intriguing molecular structure, a plausible biosynthetic pathway was proposed [97].

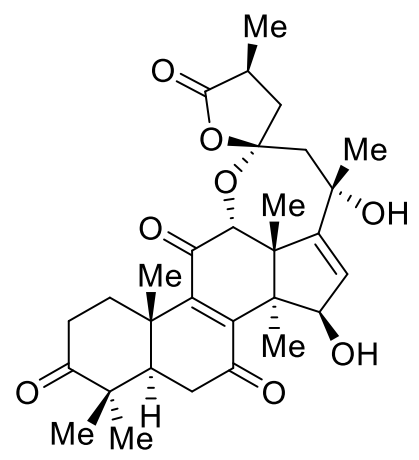

$130 \mathrm{a}$

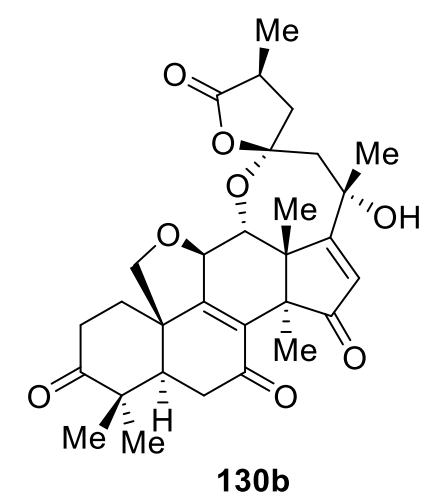

$130 \mathrm{~b}$

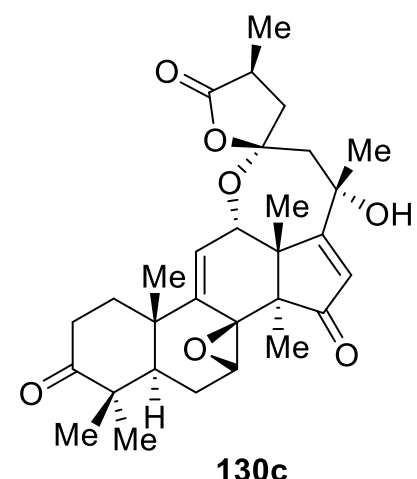

$130 \mathrm{c}$

Figure 62. Lanostane-type triterpenoid spirolactones from Ganoderma applanatum.

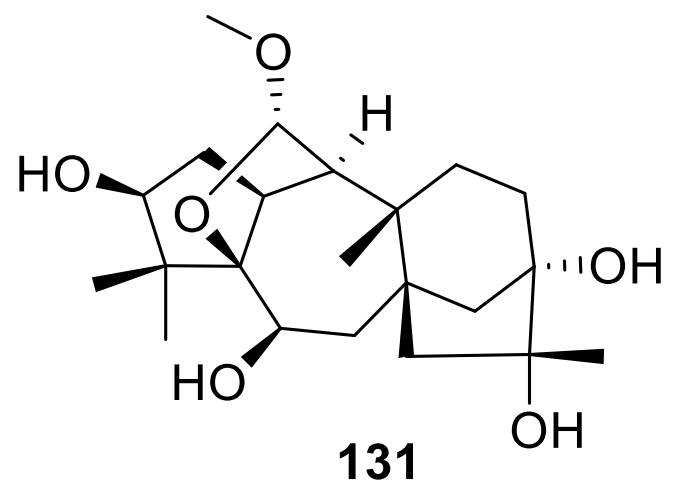

Figure 63. Structure of auriculatol A possessing a [4.6.0] spirocyclic motif.<smiles>CC(=O)CCC1=C(C)[C@H](OC(C)=O)[C@@]2(C)[C@@H](O)OCCC[C@H]12</smiles>

$132 a$<smiles>CC(=O)CCC1=C(C)[C@H](OC(C)=O)[C@@]2(C)[C@@H](O)OCCC[C@H]12</smiles>

$132 b$

Figure 64. Structure of [4.6.0] spirocyclic seconoriridone A.

The [4.6.0] spirocyclic system is amply exemplified in the natural products domain by the gelsenium alkaloids-gelsebanine (133), 14 $\alpha$-hydroxyelegansamine (134), 14 $\alpha$-hydroxygelsamydine (135) [98], 14-acetoxygelsenicine (136), 14-acetoxy-15-hydroxygelsenicine (137), 14-hydroxy-19-oxogelsenicine (138), and 14-acetoxygelseligine (139) [99] (Figure 65). 


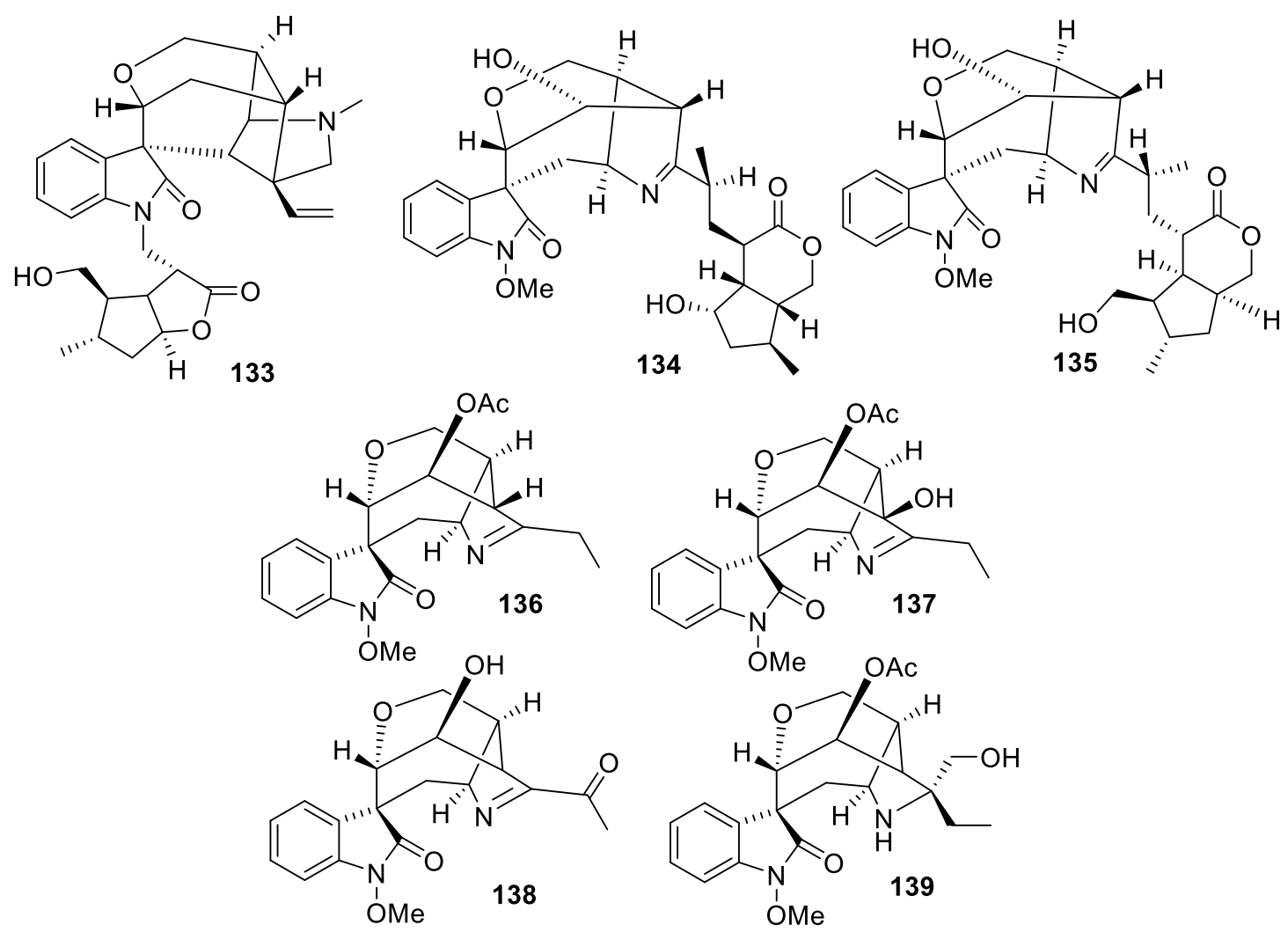

Figure 65. Structures of gelsenium alkaloids possessing a [4.6.0] spirocyclic system.

\section{0. [4.7.0] Spirocyclic System}

Spirocyclic natural products whose scaffolds contain rings larger than six-membered, e.g., [4.7.0] spirocyclic systems, are exceedingly rare. An eloquent example is provided by natural sugar-containing compounds phyllanthunin (140) recently isolated from an ethanol extract of the fruit of Phyllanthus emblica (Figure 66) [100].

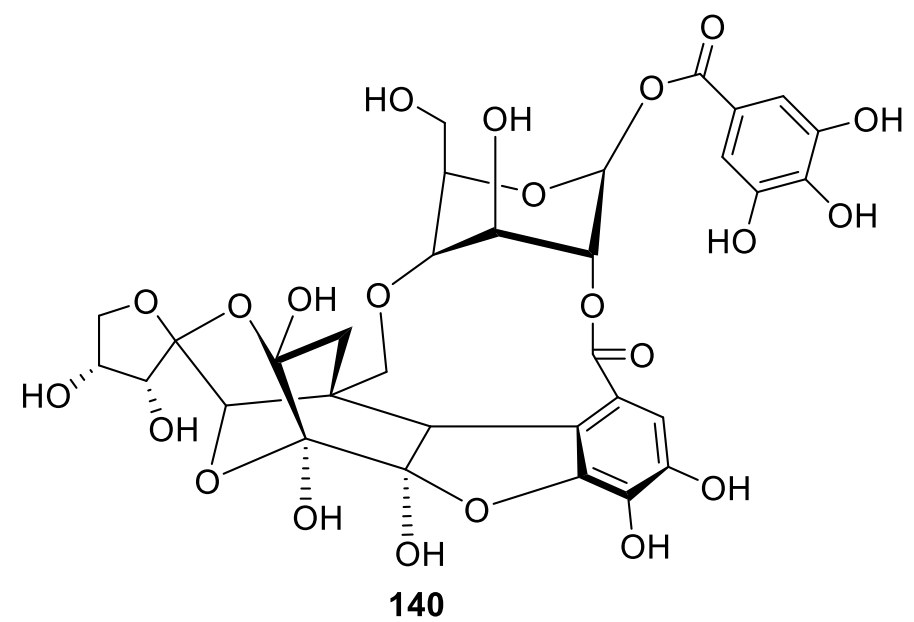

Figure 66. Natural product phyllanthunin possessing a [4.7.0] spirocyclic moiety isolated from Phyllanthus emblica.

Additionally, remarkably illustrative of the presence of [4.7.0] spirocyclic motifs in natural products, are portimines A (141) and B (142) isolated from the marine benthic dinoflagellate Vulcanodinium rugosum collected from Northland, New Zealand [101,102]. In addition to a [4.7.0] spirocyclic system, 
these compounds also contain a [4.5.0] spirocycle (Figure 67). Portimine has also been shown to induce apoptosis and reduce the growth of a variety of cancer cell lines at low nanomolar concentrations.
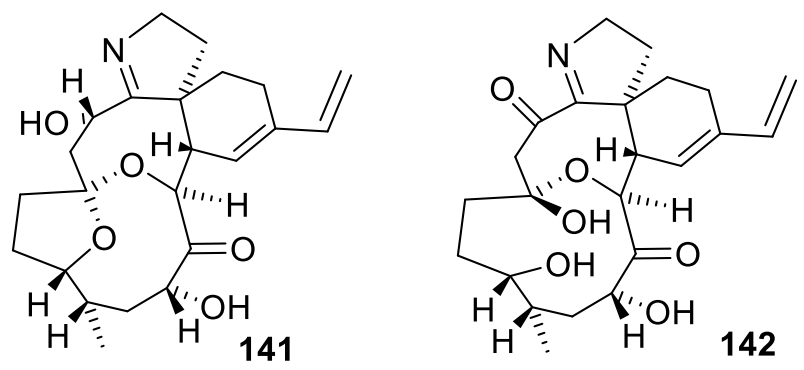

Figure 67. Portimines A and B isolated from Vulcanodinium rugosum containing both one [4.7.0] and one [4.5.0] spirocyclic motif.

\section{1. [5.5.0] Spirocyclic System}

Among natural products containing a [5.5.0] spirocyclic motif, new spirocyclic chamigrane sesquiterpenes, merulinols B (143), C (144), E (145), and F (146) are notable examples (Figure 68). These compounds were isolated from basidiomycetous endophytic fungus XG8D associated with the mangrove Xylocarpus granatum [103]. The in vitro cytotoxicity of all compounds was evaluated against three human cancer cell lines, MCF-7, Hep-G2, and KATO-3. Compound 144 selectively displayed cytotoxicity against KATO-3 cells with an $\mathrm{IC}_{50}$ value of $35.0 \mu \mathrm{M}$.<smiles>CC1(C)CC[C@@H](O)[C@H](O)[C@@]12CC=C(CO)CC2</smiles>

143<smiles>C[C@H]1[C@@H](O)CCC(C)(C)[C@]12CC=C(C(=O)O)CC2</smiles>

144<smiles>CC1=C(O)C(=O)CC(C)(C)C12CC=C(C(=O)O)CC2</smiles>

145<smiles>CC1(C)C[C@H](O)[C@@H](O)C(C)(C)C12CCC(O)(CO)CC2</smiles>

146

Figure 68. Spirocyclic chamigrane sesquiterpenes, merulinols B (143), C (144), E (145), and F (146).

Highly oxygenated acylphloroglucinol, hyperbeanol C (147), was isolated from the methanol extract of Hypericum beanie [104]. This compound contains an all-carbon [5.5.0] spirocyclic system, spiro[5.5.0] undec-2-ene-1,5-dione (Figure 69). The cytotoxicity of 147 against the cancer cell lines HL-60, SMMC-7721, PANC-1, MCF-7, K562, and SK-BR-3 was tested using the methyl thiazol tetrazalium (MTT) method with cis-platinum as the positive control. It exhibited modest cytotoxicity against K562 cells with an $\mathrm{IC}_{50} 16.9 \mu \mathrm{M}$.

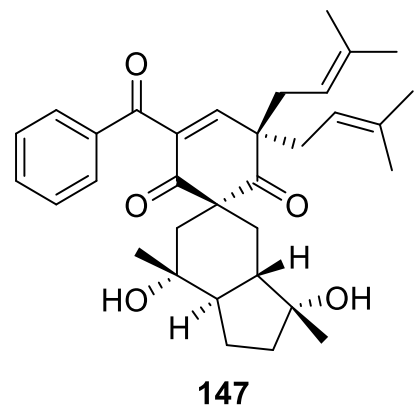

Figure 69. Hyperbeanol $\mathrm{C}$ isolated from Hypericum beanie.

Remarkable presentation of the (R)-1,7-dioxaspiro[5.5] undecane framework is found in nor-spiro-azaphilones, thielavialides A-D (148-151), and bis-spiro-azaphilone, thielavialide E (152) 
together with bis-spiro-azaphilone pestafolide A (153) (Figure 70). All these compounds were isolated from the endophytic fungal strain, Thielavia sp. PA0001, occurring in the healthy leaf tissue of aeroponically grown Physalis alkekengi [105].<smiles>C[C@@H]1CCCC2(CC3=C(CO2)[C@@H](O)C(C)(O)C3=O)O1</smiles><smiles>C[C@@H]1CCCC2(CC3=C(CO2)C(=O)C(C)(O)C3=O)O1</smiles>

151<smiles>C[C@@H]1CCCC2(CC3=C(CO2)[C@@H](O)[C@@](C)(O)C3)O1</smiles>

149<smiles>C[C@@H]1CCCC2(CC3=C(CO2)C(=O)C(C)(O)[C@@H](O)C3)O1</smiles>

152<smiles>C[C@@H]1CCCC2(CC3=C(CO2)[C@@H](O)C(C)(O)C3=O)O1</smiles><smiles>CC(=O)OC1(C)C(=O)C2=C(CC3(CCC[C@H](C)O3)OC2)C(=C2C(=O)C(C)(OC(C)=O)C(=O)C3=C2CC2(CCC[C@H](C)O2)OC3)C1=O</smiles>

Figure 70. Thielavialides A-E (148-152) and pestafolide A (153).

A very similar [5.5.0] spirocyclic moiety can be found in the structure of pteridic acids $C$ and $F$ (154 and 155, respectively) isolated in 2017 from a culture broth of the marine-derived actinomycete Streptomyces sp. SCSGAA 0027 (Figure 71). While these compounds were seen as potential leads for antibacterial drug discovery, their extensive testing for antimicrobial activity against two gorgonian pathogenic fungal strains Aspergullus versicolor SCSGAF 0096 and Aspergullus sydowii SCSGAF 0035; a human pathogenic fungal strain Candida albicans SC5314; and two bacterial strains Escherichia coli and Bacillus subtilis, showed that the compounds had only a weak antimicrobial activity [106].<smiles>CC[C@H]1[C@@H](O)C[C@]2(O[C@H]1C)O[C@H]([C@@H](C)/C=C/C(=O)O)[C@@H](C)[C@H](O)[C@H]2C</smiles>

154<smiles>CC[C@@H]1[C@H](O)C[C@@]2(O[C@H](C/C=C/C=C/C(=O)O)[C@@H](C)[C@H](O)[C@H]2C)O[C@@H]1C</smiles>

155

Figure 71. Pteridic acids $\mathrm{C}$ and $\mathrm{F}$ isolated from Streptomyces sp. SCSGAA 0027 possessing a 1,7-dioxaspiro[5.5.0]undecane motif.

A unique [5.5.0] spirocyclic skeleton formed by a hexahydropyran and a pyrrolo[2,1-c]morpholine moieties is found in pollenopyrroside A (156) and B (157) isolated from bee-collected Brassica campestris pollen (Figure 72). The Chinese team who reported these natural products in 2010 also proposed a biosynthetic pathway that involves a reaction of 3-deoxy-D-fructose and 5-oxymethyl-2-formyl-pyrrole as the key step. Biological testing of these aldehyde compounds using the 3-(4,5-dimethylthiazol-2-yl)-2,5-diphenyltetrazolium bromide (MTT) method revealed that they possess no cytotoxicity against A549, Bel7420, BGC-823, HCT-8, and A2780 cancerous cell lines at $10 \mu \mathrm{g} / \mathrm{mL}$ [107].

Another unique [5.5.0] spirocyclic skeleton is noteworthy in the context of this review. Two structurally unique spirocyclic alkaloids $\mathbf{1 5 8}$ and $\mathbf{1 5 9}$ were isolated in 2007 from the halotolerant 
B-17 fungal strain of Aspergillus variecolor (Figure 73). Both compounds possessed an intriguing spirocyclic piperazin-2,5-dione moiety and exhibited cytotoxic properties [108].
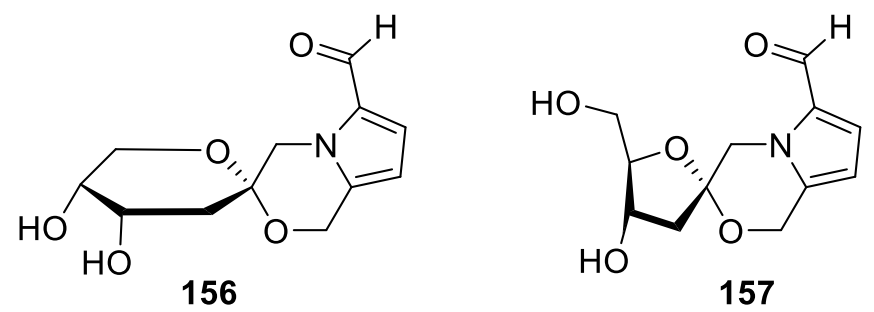

Figure 72. Pollenopyrroside A isolated from bee-collected Brassica campestris pollen.<smiles></smiles>

158

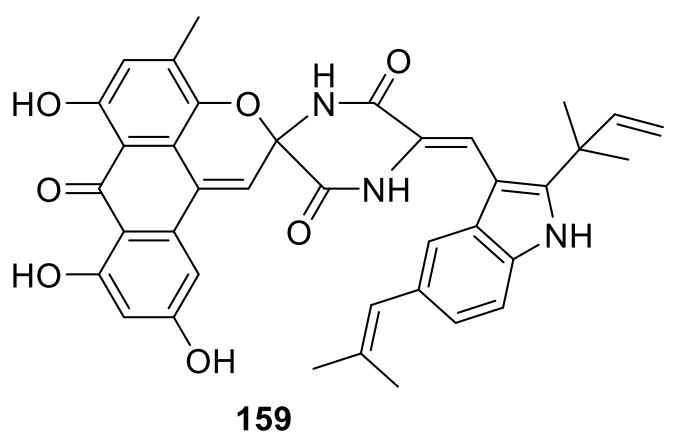

Figure 73. New spirocyclic piperazin-2,5-dione alkaloids isolated from Aspergillus variecolor.

Remarkably, in 2018, a very similar spirocyclic piperazin-2,5-dione variecolortin B (160) was isolated from the marine-derived fungus Eurotium sp. SCSIO F452 (Figure 74). The compound exhibited different antioxidative and cytotoxic activities. Interestingly, the same species gave rise to a compound possessing an even more seldomly-occurring spirocyclic moiety; namely, [5.6.0] (vide infra) [109].

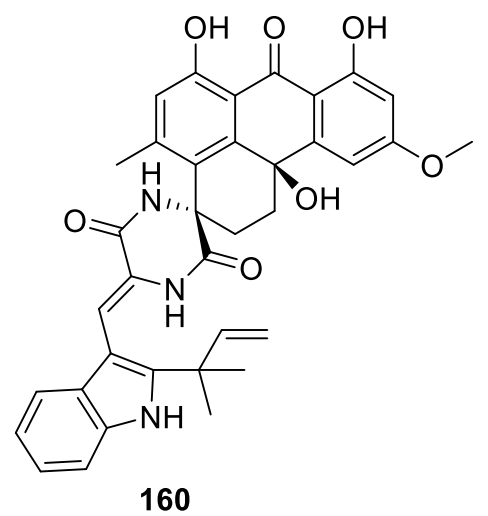

Figure 74. Spirocyclic piperazin-2,5-dione variecolortin B isolated from the marine-derived fungus Eurotium sp. SCSIO F452.

The [5.5.0] spirocyclic system occurs very prominently in bioactive meroterpenoids 161a-e and 162a-d isolated in 2019 from mangrove-derived fungus Penicillium sp. (Figure 75). Several of these compounds showed growth inhibition activity against newly hatched larvae of Helicoverpa armigera Hubner with $\mathrm{IC}_{50}$ values ranging from 50 to $200 \mu \mathrm{g} / \mathrm{mL}$, and some notable activity against Caenorhabditis elegans [110].

Workers of the ant Carebarella bicolor collected in Panama were found to contain the histrionicotoxin class of alkaloids with unusual 2,7-disubstituted-1-azaspiro[5.5]undecanol structures 163a-i (Figure 76) [111]. 

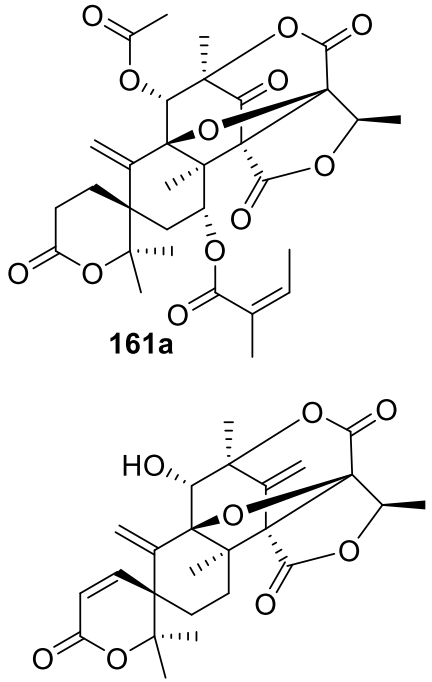

161d

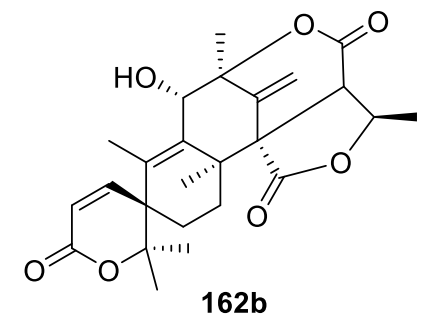

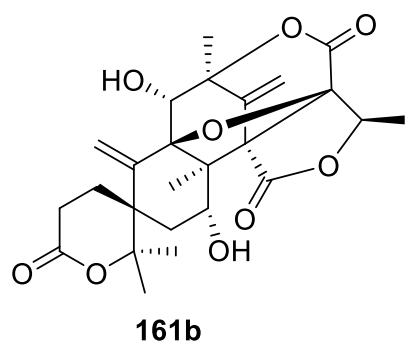

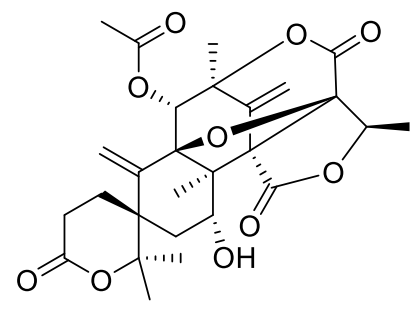

$161 e$

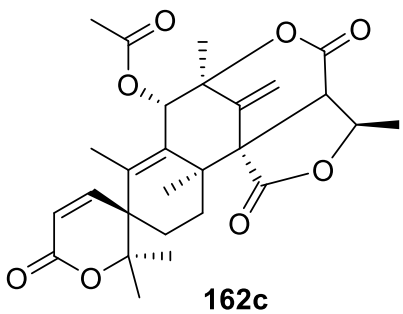

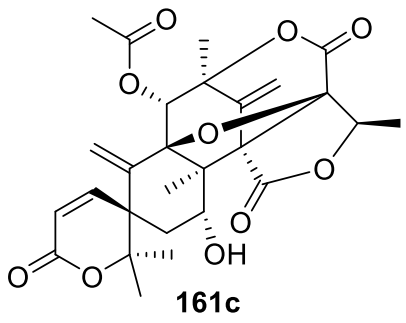
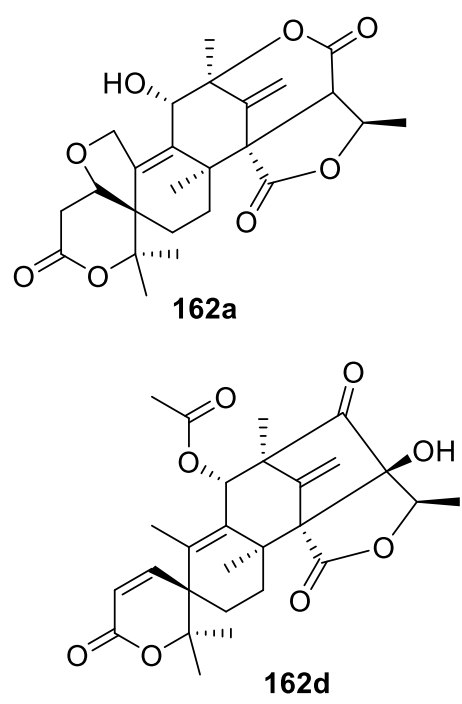

Figure 75. Bioactive [5.5.0] spirocyclic meroterpenoids isolated from mangrove-derived fungus Penicillium sp.

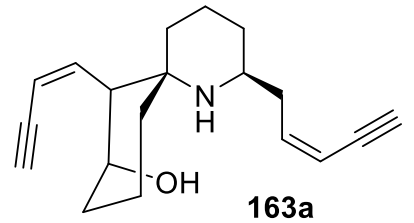<smiles>C#C/C=C\C(C(C)(C)C)[C@@]1(CO)CCC[C@@H](CCCC#C)N1</smiles><smiles>C=C/C=C\C[C@@H]1CCCC(CC2CCC2/C=C\C=C)(CC(C)(C)C)N1</smiles>

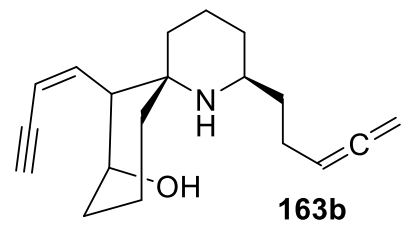

$163 b$<smiles>C=C=CCC[C@@H]1CCC[C@](CCC(C)(C)C)(C(/C=C\C=C)C2CC2)N1</smiles><smiles></smiles><smiles>C#C/C=C\C[C@@H]1CCC[C@](CO)(C(/C=C\C=C)C(C)(C)C)[C@@H]1CC</smiles><smiles>C=C=CCC[C@@H]1CCC[C@](CCC(C)(C)C)(C(/C=C/C=C)C2CC2)N1</smiles><smiles>C#CCCC[C@@H]1CCC[C@](C)(C(/C=C/C=C)C2CC2)N1</smiles>

Figure 76. Alkaloids 163-i of the histrionicotoxin class isolated from ant Carebarella bicolor.

\section{2. [5.6.0] Spirocyclic System}

An interesting group of natural products representative of this spirocyclic system are periplosides (164), a spiro-orthoester group-containing pregnane-type glycosides discovered in the course of phytochemical investigation of the root bark of Periploca sepium (Figure 77). The [5.6.0] spirocyclic orthoester core is distinctly modified with a steroid unit on one hand $\left(\mathrm{R}^{1}\right)$ and with an oligosaccharide moiety on the other $\left(\mathrm{R}^{2}\right)$. The compounds were evaluated for their inhibitory activities against the 
proliferation of T-lymphocytes. As a result, one specific compound (periploside C), the most abundant glycoside containing a spiro-orthoester moiety found in the plant, exhibited the most favorite selective index value $(\mathrm{SI}=82.5)$. The inhibitory activity and the SI value appear to depend on the constitution of the saccharide chain [112].

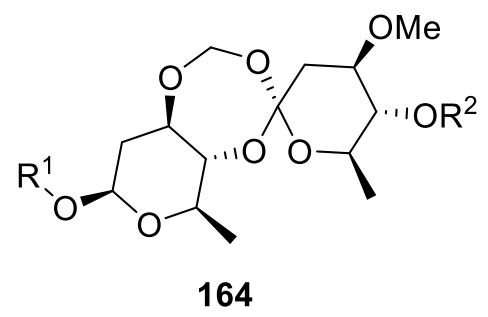

Figure 77. General structure of [5.6.0] spirocyclic orthoester periplosides.

The remarkable, from a structural perspective, spirolide G (165), was isolated from Danish strains of toxigenic dinoflagellate Alexandrium ostenfeldii. The toxicological profile of this compound was evaluated [113]. Interestingly, in addition to the spirocyclic [5.6.0] moiety in question, spirolide G (165) contains two others; namely, a [4.4.0] and a [4.5.0] motif (Figure 78).

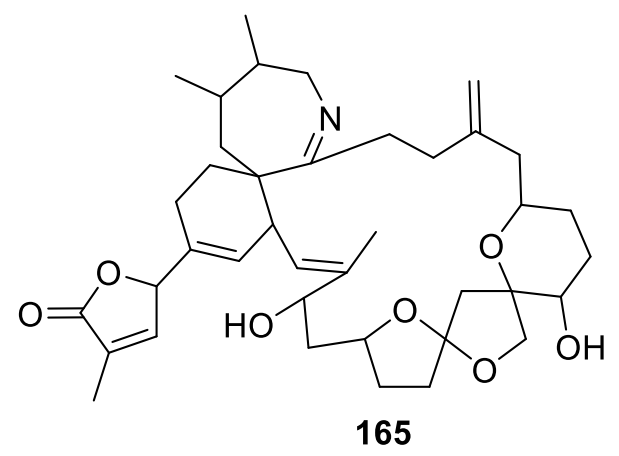

Figure 78. Spirolide G isolated from toxigenic dinoflagellate Alexandrium ostenfeldii.

Referring back to the chemical investigation of the marine-derived fungus Eurotium sp. SCSIOF452 discussed above in connection with compounds belonging to the [5.5.0] spirocyclic system, an intriguing [5.6.0] spirocyclic compound $\mathbf{1 6 6}$ (Figure 79) was also isolated from the same species [109]. This is a case of one species giving rise to a diversity of spirocyclic frameworks, underscoring the significance of spirocycles in the natural product realm. One particular example of such spirocycle diversity derived from a single organism is discussed in Section 13 below.

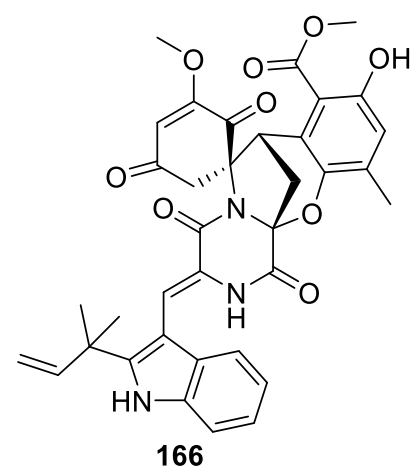

Figure 79. A [5.6.0] spirocyclic compound isolated from marine-derived fungus Eurotium sp. SCSIO F452. 
A [5.6.0] spirocyclic moiety is recognizable in the new sesquiterpene dimer vieloplain $G$ (167) isolated in 2019 from the roots of Xylopia vielana (Figure 80). This compound showed considerable cytotoxicity against DU145 cells with an $\mathrm{IC}_{50}$ value of $9.5 \mu \mathrm{M}$ [114].

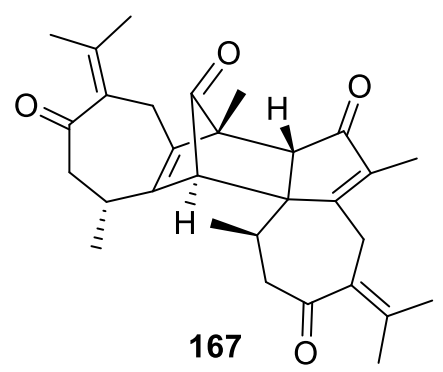

Figure 80. Vieloplain G isolated from Xylopia vielana containing a [5.6.0] spirocyclic scaffold.

\section{3. [6.6.0] Spirocyclic System}

This type of spirocyclic framework is exceedingly rare in the natural product domain, with only one example of unique 1-oxaspiro[6.6]tridecane 168, a spirocyclic nortriterpenoid Spiroschincarin A isolated from the fruit of Schisandra incarnate (Figure 81) [115].

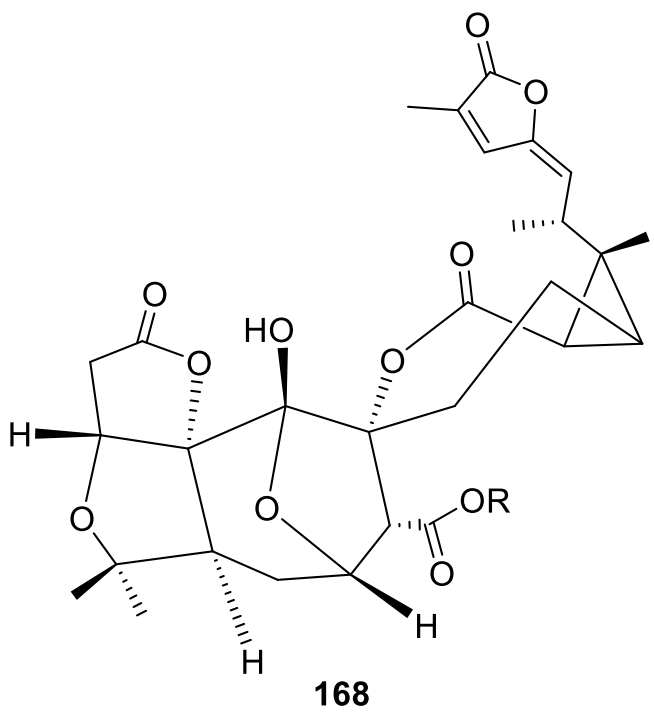

Figure 81. Spiroschincarin A isolated from the fruit of Schisandra incarnate.

\section{Plant Species Distinctly Rich in Diverse Spirocyclic Natural Products}

Some cases when the same plant or microorganism gave rise to secondary metabolites with several structurally-diverse spirocyclic frameworks were discussed above. However, one recent example published in 2019, describing a chemical investigation of monoterpenoid indole alkaloids isolated from the roots of Gelsemium elegans (also briefly discussed in Section 8 of this review), stands out from the standpoint of hitherto unprecedented skeletal diversity [116]. In particular, the following spirocyclic frameworks were encountered among the natural products isolated from this species: [4.5.0]—featured in 19-oxogelsevirine (169), gelsevirine (170), and koumimine (171); [4.7.0]—featured in gelsedethenine (172); and a unique [4.8.0] system-featured in humantenine (173) and 19,20-epoxyhumantenine (174) (Figure 82). 


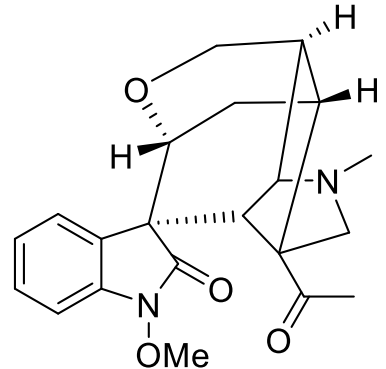

$[4.5 .0]$

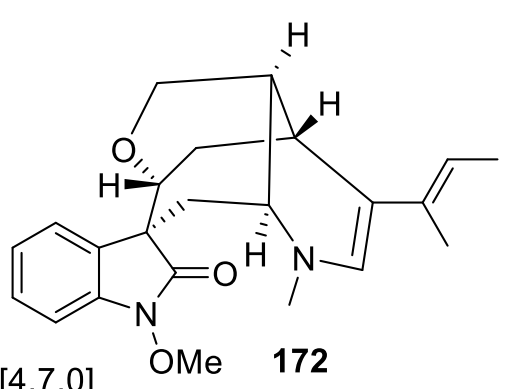

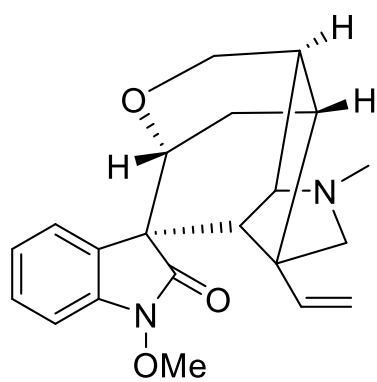

[4.5.0]

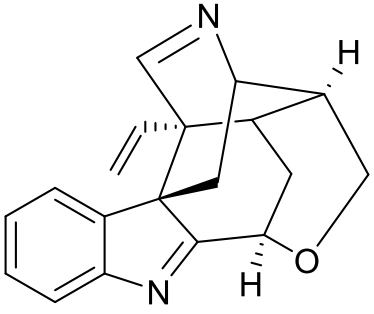

$[4.5 .0]$
171

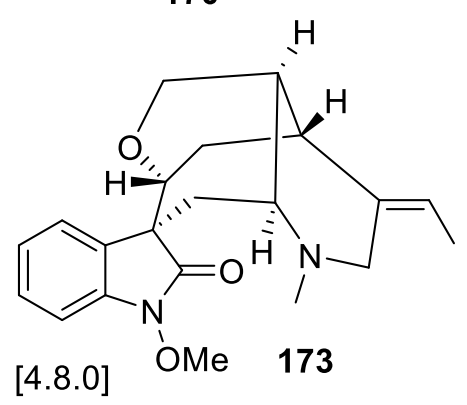

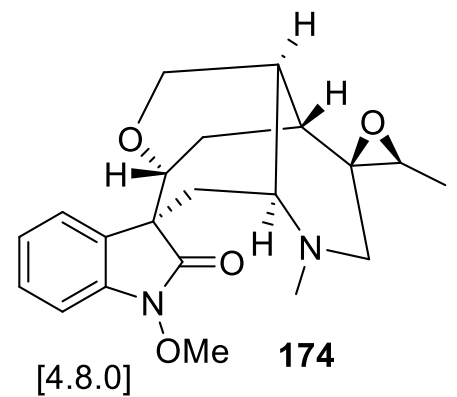

Figure 82. Structurally diverse spirocyclic frameworks isolated from a single plant species (Gelsemium elegans).

\section{Conclusions and Perspectives}

Spirocyclic scaffolds are omnipresent in the natural products domain. By analyzing the diversity of spirocyclic systems reported for natural products in the literature, one can appreciate an uneven distribution of such motifs according to the spirocycle type: certain motifs are more abundant than others and some are rather scarce, exemplified by only a handful of naturally occurring compounds. The most widespread are the [5.5.0], [4.5.0], and [4.4.0] spirocycles. In terms of associated bioactivities discovered and reported for spirocyclic products, these are mostly limited to the usual profiling in the context of antiproliferative, anti-inflammatory, and antimicrobial activities. However, the strong connections of spirocyclic frameworks to the natural product domain and their emerging privileged motif status in the synthetic drug discovery argues in favor of the need for more thorough panel profiling of all newly-discovered natural products, as novel and hitherto unprecedented bioactivity leads could be discovered. Certain scarcely-populated areas of the spirocyclic natural product space can be specifically developed into synthetic libraries and investigated for bioactivity. More spirocycles appear to have been discovered in the last 5-10 years, with an apparent advent of plant species giving rise to several types of spirocyclic frameworks in the course of their chemical investigation. The spirocyclic natural product discovery, therefore, appears to be on the rise and is likely to inspire new scaffolds for drug design and screening library development.

Funding: This research was funded by the Ministry for Science and Education of the Russian Federation under the Federal Target Program, "High-Priority Areas for Research and Development in Science and Technology for Russia in 2014-2020," grant number (RFMEFI57718X0285).

Acknowledgments: The authors are indebted to Dmitry Dar'in of Saint Petersburg University for helpful discussions regarding this work.

Conflicts of Interest: The authors declare no conflicts of interest.

\section{References}

1. Newman, D.J.; Cragg, G.M. Natural products as sources of new drugs over the 30 years from 1981 to 2010. J. Nat. Prod. 2012, 75, 311-335. [CrossRef] [PubMed] 
2. Rios, R. Enantioselective methodologies for the synthesis of spiro compounds. Chem. Soc. Rev. 2012, 41, 1060-1074. [CrossRef] [PubMed]

3. Zheng, Y.; Tice, C.M.; Singh, S.B. The use of spirocyclic scaffolds in drug discovery. Bioorg. Med. Chem. Lett. 2014, 24, 3673-3682. [CrossRef] [PubMed]

4. Zhao, H.; Akritopoulou-Znze, I. When analoging is not enough: Scaffold discovery in medicinal chemistry. Exp. Opin. Drug. Discov. 2010, 5, 123-134. [CrossRef] [PubMed]

5. Smith, L.K.; Baxendale, I.R. Total syntheses of natural products containing spirocarbocycles. Org. Biomol. Chem. 2015, 13, 9907-9933. [CrossRef] [PubMed]

6. Quintavalla, A. Spirolactones: Recent advances in natural products, bioactive compounds and synthetic strategies. Curr. Med. Chem. 2018, 25, 917-962. [CrossRef] [PubMed]

7. Marti, C.; Carreira, E.M. Construction of spiro[pyrrolidine-3,3'-oxindoles] - recent applications to the synthesis of oxindole alkaloids. Eur. J. Org. Chem. 2003, 12, 2209-2219. [CrossRef]

8. Tsuji, N.; Kobayashi, M.; Wakisaka, Y.; Kawamura, Y.; Mayama, M.; Matsumoto, K. New antibiotics, griseusins A and B. Isolation and characterization. J. Antibiot. 1976, 29, 7-9. [CrossRef]

9. Briar, J.; Brimble, N.; Brimble, M.A. Synthesis of the griseusin B framework via a one-pot annulation-methylation-double deprotection-spirocyclization sequence. Org. Lett. 2013, 15, 2006-2009.

10. Galliford, C.V.; Scheidt, K.A. Pyrrolidinyl-spirooxindole natural products as inspirations for the development of potential therapeutic agents. Angew. Chem. Int. Ed. 2007, 46, 8748-8758. [CrossRef]

11. Richter, R.; von Reuß, S.H.; König, W.A. Spirocyclopropane-type sesquiterpene hydrocarbons from Schinus terebinthifolius raddi. Phytochemistry 2010, 71, 1371-1374. [CrossRef] [PubMed]

12. Tanaka, S.; Honmura, Y.; Uesugi, S.; Fukushi, E.; Tanaka, K.; Maeda, H.; Kimura, K.; Nehira, T.; Hashimoto, M. Cyclohelminthol X, a hexa-substituted spirocyclopropane from Helminthosporium velutinum yone96: Structural elucidation, electronic circular dichroism analysis, and biological properties. J. Org. Chem. 2017, 82, 5574-5582. [CrossRef] [PubMed]

13. Murakami, N.; Ye, Y.; Kawanishi, M.; Aoki, S.; Kudo, N.; Yoshida, M.; Nakayama, E.E.; Shioda, T.; Koboyashi, M. New rev-transport inhibitor with anti-HIV activity from Valerianae Radix. Bioorg Med. Chem Lett. 2002, 12, 2807-2810. [CrossRef]

14. Stransky, K.; Semerdžievab, M.; Otmara, M.; Procházkaa, Ž.; Buděšínskýa, M.; Ubika, K.; Kohoutováa, J.; Streinz, L. Antifungal antibiotic from the mushroom Agrocybe aegerita (BRIG.) SING. Collect. Czech. Chem. Commun. 1992, 57, 590-603. [CrossRef]

15. Bollinger, P.; Sigg, H.P.; Weber, H.P. Die struktur von ovalicin. Helv. Chim. Acta. 1973, 56, 819-830. [CrossRef]

16. Newman, D.J.; Cragg, G.M. Natural products of therapeutic importance. In Comprehensive Natural Products II; Liu, H.W., Mander, L., Eds.; Elsevier: Amsterdam, The Netherlands, 2010; pp. 623-650, ISBN 978-0-08-045382-8.

17. Yadav, J.S.; Reddy, P.N.; Reddy, B.V.S. Stereoselective total synthesis of (-) -ovalicin. Synlett 2010, 457-462. [CrossRef]

18. Ichimura, M.; Ogawa, T.; Takahashi, K.-I.; Kobayashi, E.; Kawamoto, I.; Yasuzawa, T.; Takahashi, I.; Nakano, H. Duocarmycin SA, a new antitumor antibiotic from Streptomyces sp. J. Antibiot. (Tokyo) 1990, 43, 1037-1038. [CrossRef]

19. Ko, K.; Lee, S.H.; Kim, S.H.; Kim, E.H.; Oh, K.B.; Shin, J.; Oh, D.C. Lajollamycins, nitro group-bearing spiro- $\beta$-lactone- $\gamma$-lactams obtained from a marine-derived Streptomyces sp. J. Nat. Prod. 2014, 77, 20999-22104. [CrossRef]

20. Tian, J.; Zhao, Q.-S.; Zhang, H.-J.; Lin, Z.-W.; Sun, H.-D. New cleroindicins from Clerodendrum indicum. J. Nat. Prod. 1997, 60, 766-769. [CrossRef]

21. Kouno, I.; Hashimoto, M.; Enjoji, S.; Takahashi, M.; Kaneto, H.; Yang, C.S. Isolation of neoanisatin derivatives from the pericarps of Illicium majus with other constituents. Chem. Pharm. Bull. 1991, 39, 1773-1778. [CrossRef]

22. Edwards, R.L.; Maitland, D.J.; Oliver, C.L.; Pacey, M.S.; Shields, L.; Whalley, A.J. Metabolites of the higher fungi. Part 31. ${ }^{1}$ longianone, a $\mathrm{C}_{7} \mathrm{H}_{6} \mathrm{O}_{4}$ spirobicyclic lactone from the fungus Xylaria longiana (Rehm.). J. Chem. Soc. Perkin Trans. 1 1999, 715-719. [CrossRef]

23. Perali, R.S.; Kalapati, S. First enantioselective total synthesis of (S)-(-)-longianone. Tetrahedron 2012, 68, 3725-3728. [CrossRef] 
24. Aramaki, Y.; Chiba, K.; Tada, M. Spiro-lactones, hyperolactone A-D from Hypericum chinense. Phytochemistry 1995, 38, 1419-1421. [CrossRef]

25. Gao, X.; Chooi, Y.H.; Ames, B.D.; Wang, P.; Walsh, C.T.; Tang, Y. Fungal indole alkaloid biosynthesis: Genetic and biochemical investigation of the tryptoquialanine pathway in Penicillium aethiopicum. J. Am. Chem. Soc. 2011, 133, 2729-2741. [CrossRef] [PubMed]

26. Nicolaou, K.C.; Sanchini, S.; Sarlah, D.; Lu, G.; Wu, T.R.; Nomura, D.K.; Cravatt, B.F.; Cubitt, B.; de la Torre, J.C.; Hessell, A.J.; et al. Design, synthesis, and biological evaluation of a biyouyanagin compound library. PNAS 2011, 108, 6715-6720. [CrossRef]

27. Tuchinda, P.; Munyoo, B.; Pohmakotr, M.; Thinapong, P.; Sophasan, S.; Santisuk, T.; Reutrakul, V. Cytotoxic styryl-lactones from the leaves and twigs of Polyalthia crassa. J. Nat. Prod. 2006, 69, 1728-1733. [CrossRef]

28. Nukina, M.; Hirota, H. Pyrenolide D, a new cytotoxic fungal metabolite from Pyrenophora teres. Biosci. Biotechnol. Biochem. 1992, 56, 1158-1159. [CrossRef]

29. González, A.G.; Francisco, C.G.; Freire, R.; Hernández, R.; Salazar, J.A.; Suárez, E.C. C 12 stereochemistry of $\alpha$ - and $\beta$-levantenolide carbon-13 NMR spectra of labdanolic diterpenes. Tetrahedron Lett. 1976, 17, 1897-1898. [CrossRef]

30. Kiem, P.V.; Anh, H.T.; Nhiem, N.X.; Minh, C.V.; Thuy, N.T.; Yen, P.H.; Hang, D.T.; Tai, B.H.; Mathema, V.B.; Koh, Y.S.; et al. Labdane-type diterpenoids from the Rhizomes of Hedychium coronarium inhibit lipopolysaccharide-stimulated production of pro-inflammatory cytokines in bone marrow-derived dendritic cells. Chem. Pharm. Bull. 2012, 60, 246-250. [CrossRef]

31. Yang, X.-Z.; Zhu, J.-Y.; Tang, C.-P.; Ke, C.-Q.; Lin, G.; Cheng, T.-Y.; Rudd, J.A.; Ye, Y. Alkaloids from roots of Stemona sessilifolia and their antitussive activities. Planta Med. 2009, 75, 174-177. [CrossRef]

32. An, F.-L.; Luo, J.; Li, R.-J.; Luo, J.-G.; Wang, X.-B.; Yang, M.-H.; Yang, L.; Yao, H.-Q.; Sun, H.-B.; Chen, Y.-J.; et al. Spirotrichilins A and B two rearranged spirocyclic Limonoids from Trichilia connaroides. Org. Lett. 2016, 18, 1924-1927. [CrossRef] [PubMed]

33. Wang, Y.-N.; Xia, G.-Y.; Wang, L.-Y.; Ge, G.-B.; Zhang, H.-W.; Zhang, J.-F.; Wu, Y.-Z.; Lin, S. Purpurolide A, 5/5/5 spirocyclic sesquiterpene lactone in nature from the endophytic fungus Penicillium purpurogenum. Org. Lett. 2018, 20, 7341-7344. [CrossRef] [PubMed]

34. Shiobara, Y.; Asakawa, Y.; Kodama, M.; Yasuda, K.; Takemoto, T. Curcumenone, curcumanolide A and cur-cumanolide B, three sesquiterpenoids from Curcuma zedoaria. Phytochemistry 1985, 24, 2629-2633. [CrossRef]

35. Schripsema, J.; Caprini, G.P.; Dagnino, D. Revision of the structures of citrifolinin A, citrifolinoside, yopaaoside A, yopaaoside B, and morindacin, iridoids from Morinda citrifolia L. and Morinda coreia Ham. Org. Lett. 2006, 8, 5337-5340. [CrossRef]

36. Pang, X.; Lin, X.; Yang, J.; Zhou, X.; Yang, B.; Wang, J.; Liu, Y. Spiro-phthalides and isocoumarins isolated from the marine-sponge-derived fungus Setosphaeria sp. SCSIO41009. J. Nat. Prod. 2018, 81, 1860-1868. [CrossRef]

37. Nielsen, K.F.; Mansson, M.; Jens, C.R.; Frisvad, C.; Larsen, T.O. Dereplication of microbial natural products by LC-DAD-TOFMS. J. Nat. Prod. 2011, 74, 2338-2348. [CrossRef]

38. Liu, Y.; Ding, G.; Li, Y.; Qu, J.; Ma, S.; Lv, H.; Liu, Y.; Wang, W.; Dai, J.; Tang, Y.; et al. Structures and absolute configurations of penicillactones A-C from an endophytic microorganism, Penicillium dangeardii Pitt. Org. Lett. 2013, 15, 5206-5209. [CrossRef]

39. Nakajima, M.; Itoi, K.; Takamatsu, Y.; Kinoshita, T.; Okazaki, T.; Kawakubo, K.; Shindo, M.; Honma, T.; Tohjigamori, M.; Haneishi, T. Hydantocidin: A new compound with herbicidal activity from Streptomyces hygroscopicus. J. Antibiot. 1991, 44, 293-300. [CrossRef]

40. Luo, Q.; Wei, X.Y.; Yang, J.; Luo, J.F.; Liang, R.; Tu, Z.C.; Cheng, Y.X. Spiro meroterpenoids from Ganoderma applanatum. J. Nat. Prod. 2017, 80, 61-70. [CrossRef]

41. Cui, C.B.; Kakeya, H.; Okada, G.; Onose, R.; Osada, H. Novel mammalian cell cycle inhibitors, tryprostatins A, B and other diketopiperazines produced by Aspergillus fumigatus. J. Antibiot. 1996, 49, 527-533. [CrossRef]

42. Bindra, J.S. Oxindole alkaloids. In The Alkaloids; Manske, R.H.F., Ed.; Academic Press: New York, NY, USA, 1973; pp. 84-121, ISBN 9780080865386. 
43. Váradi, A.; Marrone, G.F.; Palmer, T.C.; Narayan, A.; Szabó, M.R.; Le Rouzic, V.; Grinnell, S.G.; Subrath, J.J.; Warner, E.; Kalra, S.; et al. Mitragynine/corynantheidine pseudoindoxyls as opioid analgesics with mu agonism and delta antagonism, which do not recruit $\beta$-arrestin-2. J. Med. Chem. 2016, 59, 8381-8397. [CrossRef] [PubMed]

44. Zarembo, J.E.; Douglas, B.; Valenta, J.; Weisbach, J.A. Metabolites of mitragynine. J. Pharm. Sci. 1974, 63, 1407-1415. [CrossRef] [PubMed]

45. Hesse, M.; Philipsborn, W.V.; Schumann, D.; Spiteller, G.; Spiteller-Friedmann, M.; Taylor, W.I.; Schmid, H.; Karrer, P. Die Strukturen von C-Fluorocurin, C-Mavacurin und Pleiocarpamin. 57. Mitteilung über Curare-Alkaloide. Helv. Chim. Acta 1964, 47, 878-911. [CrossRef]

46. Wang, F.; Fang, Y.; Zhu, T.; Zhang, M.; Lin, A.; Gu, Q.; Zhu, W. Seven new prenylated indole diketopiperazine alkaloids from holothurian-derived fungus Aspergillus fumigatus. Tetrahedron 2008, 64, 7986-7991. [CrossRef]

47. Birch, A.J.; Wright, J.J. Studies in relation to biosynthesis-XLII: The structural elucidation and some aspects of the biosynthesis of the brevianamides-A and -E. Tetrahedron 1970, 26, 2329-2344. [CrossRef]

48. Phillipson, J.D.; Supavita, N. Alkaloids of uncaria elliptica. Phytochemistry 1983, 22, 1809-1813. [CrossRef]

49. Ren, H.; Liu, R.; Chen, L.; Zhu, T.; Zhu, W.M.; Gu, Q.Q. Two new hetero-spirocyclic $\gamma$-lactam derivatives from marine sediment-derived fungus Aspergillus sydowi $\mathrm{D}_{2-6}$. Arch. Pharm. Res. 2010, 33, 499-502. [CrossRef]

50. Pedras, M.S.C.; Suchy, M.; Ahiahonu, P.W.K. Unprecedented chemical structure and biomimetic synthesis of erucalexin, a phytoalexin from the wild crucifer Erucastrum gallicum. Org. Biomol. Chem. 2006, 4, 691-701. [CrossRef]

51. Ariza, M.R.; Larsen, T.O.; Petersen, B.O.; Duus, J.O.; Barrero, A.F. Penicillium digitatum metabolites on synthetic media and citrus fruits. J. Agric. Food. Chem. 2002, 50, 6361-6365. [CrossRef]

52. Lee, M.; Lin, H.Y.; Cheng, F.; Chiang, W.; Kuo, Y. Isolation and characterization of new lactam compounds that inhibit lung and colon cancer cells from adlay (Coix lachryma-jobi L. var. ma-yuen Stapf) bran. Food. Chem. Toxicol. 2008, 46, 1933-1939. [CrossRef]

53. Yang, X.L.; Li, Z.Z.; Zhang, S.; Yu, H.; Zhu, H.J.; Luo, D.Q. A new spirocyclic compound from the liquid culture of entomogenous fungus Isaria cateniannulata. J. Asian Nat. Prod. Res. 2012, 14, 1093-1096. [CrossRef] [PubMed]

54. Liu, M.; Sun, W.; Shen, L.; Hao, X.; Al, A.; Weaam, H.; Lin, S.; Li, H.; Gao, W.; Wang, J.; et al. Bipolaricins A-I, ophiobolin-type tetracyclic sesterterpenes from a phytopathogenic Bipolaris sp. fungus. J. Nat. Prod. 2019, 82, 2897-2906. [CrossRef] [PubMed]

55. Pandey, R.C.; Toussaint, M.W.; Stroshane, R.M.; Kalita, C.C.; Aszalos, A.A.; Garretson, A.L.; Wei, T.T.; Byrne, K.M.; Stroshane, R.M.; White, R.J. Fredericamycin A a new antitumor antibiotic. I. Production, isolation and physicochemical properties. J. Antibiot. (Tokyo) 1981, 34, 1389-1401. [CrossRef] [PubMed]

56. Misra, R.; Pandey, R.C.; Silverton, J.V. Fredericamycin A, an antitumor antibiotic of a novel skeletal type. J. Am. Chem. Soc. 1982, 104, 4478-4479. [CrossRef]

57. Li, Z.Y.; Qi, F.M.; Zhi, D.J.; Hu, Q.L.; Liu, Y.H.; Zhang, Z.X.; Fei, D.Q. A novel spirocyclic triterpenoid and a new taraxerane triterpenoid from Teucrium viscidum. Org. Chem. Front. 2017, 42-46. [CrossRef]

58. Matsunaga, S.; Morita, R.; Ishida, T.; Inoue, M.; Shigi, M.; Miyamae, A. The structure of spirosupinanonediol, a triterpenoid bearing a novel skeletal system from Euphorbia supina. J. Chem. Soc. Chem. Commun. 1984, 1128-1129. [CrossRef]

59. Ye, M.; Xiong, J.; Zhu, J.-J.; Hong, J.-L.; Zhao, Y.; Fan, H.; Yang, G.-X.; Xia, G.; Hu, J.-F. Leonurusoleanolides E-J, minor spirocyclic triterpenoids from Leonurus japonicus fruits. J. Nat. Prod. 2014, 77, 178-182. [CrossRef]

60. Asim, M.; Hussien, H.; Poveda, L.; Arnason, J.T.; Durst, T. Triterpenoids from the bark of Ruptiliocarpon caracolito. Phytochemistry 2010, 71, 1418-1422. [CrossRef]

61. Ni, G.; Li, J.Y.; Mai, Z.P.; Yu, D.Q. Belamcandanes A and B, two unprecedented tricyclic-iridal triterpenoids from Belamcanda chinensis. Tetrahedron Lett. 2018, 59, 151-155. [CrossRef]

62. Hao, Z.Y.; Liang, D.; Luo, H.; Liu, Y.F.; Ni, G.; Zhang, Q.J.; Li, L.; Si, Y.K.; Sun, H.; Chen, R.Y.; et al. Bioactive sesquiterpenoids from the rhizomes of Acorus calamus. J. Nat. Prod. 2012, 75, 1083-1089. [CrossRef]

63. Kawaguchi, Y.; Ochi, T.; Takaishi, Y.; Kawazoe, K.; Lee, K.H. New sesquiterpenes from Capsicum annuum. J. Nat. Prod. 2004, 67, 1893-1896. [CrossRef] [PubMed]

64. MacMillan, J. Griseofulvin. Part VII. Dechlorogriseofulvin. J. Chem. Soc. 1953, 1697-1702. [CrossRef]

65. Petersen, A.B.; Rønnest, M.H.; Larsen, T.O.; Clausen, M.H. The chemistry of Griseofulvin. Chem. Rev. 2014, 114, 12088-12107. [CrossRef] [PubMed] 
66. Murakami, T.; Sasaki, A.; Fukushi, E.; Kawabata, J.; Hashimoto, M.; Okuno, T. Lambertellol C, a labile and novel biosynthetic congener of lambertellols A and B. Bioorg. Med. Chem. Lett. 2005, 15, 2587-2590. [CrossRef] [PubMed]

67. Balansa, W.; Islam, R.; Fontaine, F.; Piggott, A.M.; Zhang, H.; Xiao, X.; Webb, T.I.; Gilbert, D.F.; Lynch, J.W.; Capon, R.J. Sesterterpene glycinyl-lactams: A new class of glycine receptor modulator from Australian marine sponges of the genus Psammocinia. Org. Biomol. Chem. 2013, 11, 4695-4701. [CrossRef] [PubMed]

68. Avcibasi, H.; Anil, H.; Toprak, M. Four terpenoids from Cedrus libanotica. Phytochemistry 1987, 10, $2852-2854$. [CrossRef]

69. Riedlinger, J.; Reicke, A.; Zähner, H.; Krismer, B.; Bull, A.T.; Maldonado, L.A.; Ward, A.C.; Goodfellow, M.; Bister, B.; Bischoff, D.; et al. Abyssomicins, inhibitors of the para-aminobenzoic acid pathway produced by the marine Verrucosispora strain AB-18-032. J. Antibiot. 2004, 57, 271-279. [CrossRef]

70. Holtzel, A.; Dieter, A.; Schmid, D.G.; Brown, R.; Goodfellow, M.; Beil, W.; Jung, G.; Fiedler, H.P. Lactonamycin $\mathrm{Z}$, an antibiotic and antitumor compound produced by Streptomyces sanglieri strain $\mathrm{AK}$ 623. J. Antibiot. 2003, 56, 1058-1061. [CrossRef]

71. Bussey, R.O.; Kaur, A.; Todd, D.A.; Egan, J.M.; El- Elimat, T.; Graf, T.N.; Raja, H.A.; Oberlies, N.H.; Cech, N.B. Comparison of the chemistry and diversity of endophytes isolated from wild-harvested and greenhouse-cultivated yerba mansa (Anemopsis californica). Phytochem. Lett. 2015, 202-208. [CrossRef]

72. Asai, T.; Taniguchi, T.; Yamamoto, T.; Monde, K.; Oshima, Y. Structures of spiroindicumides A and B, unprecedented carbon skeletal spirolactones, and determination of the absolute configuration by vibrational circular dichroism exciton approach. Org. Lett. 2013, 15, 4320-4323. [CrossRef]

73. Murakami, T.; Morikawa, Y.; Hashimoto, M.; Okuno, T.; Harada, Y. Lambertellols A and B, novel 3,4-dihydronaphthalen-1(2H)-ones with spiro-butenolide produced by Lambertella sp.1346. Org. Lett. 2004, 6, 157-160. [CrossRef] [PubMed]

74. Sun, Z.L.; Zhang, M.; Zhang, J.F.; Feng, J. Antifungal and cytotoxic activities of the secondary metabolites from endophytic fungus Massrison sp. Phytomedicine 2011, 18, 859-862. [CrossRef] [PubMed]

75. Feng, Y.; Wang, L.; Niu, S.; Li, L.; Si, Y.; Liu, X.; Che, Y. Naphthalenones from a Perenniporia sp. inhabiting the larva of a phytophagous Weevil, Euops chinesis. J. Nat. Prod. 2012, 75, 1339-1345. [CrossRef] [PubMed]

76. Jakupovic, J.; Banerjee, S.; Bohlmann, F.; King, R.M.; Robinson, H. New diterpenes from chiliotrichium rosmarinifolium and nardophyllum lanatum. Tetrahedron 1986, 42, 1305-1313. [CrossRef]

77. Sánchez, M.; Mazzuca, M.; Veloso, M.J.; Fernández, L.R.; Siless, G.; Puricelli, L.; Palermo, J.A. Cytotoxic terpenoids from Nardophyllum bryoides. Phytochemistry 2010, 71, 1395-1399. [CrossRef]

78. Yang, X.-W.; Li, S.-M.; Li, Y.-L.; Xia, J.-H.; Wu, L.; Shen, Y.-H.; Tian, J.-M.; Wang, N.; Liu, Y.; Zhang, W.-D. Abiespiroside A, an unprecedented sesquiterpenoid spirolactone with a 6/6/5 ring system from Abies delavayi. Eur. J. Org. Chem. 2010, 34, 6531-6534. [CrossRef]

79. Coelho, F.; Diaz, G. Studies on the synthesis of ( \pm )-pathylactone A, a nor-sesquiterpene lactone isolated from marine sources. Tetrahedron 2002, 58, 1647-1656. [CrossRef]

80. Lochynski, S.; Frąckowiak, B.; Olejniczak, T.; Ciunik, Z.; Wawrzeńczyk, C. Lactones. Part 15: Synthesis of chiral spirolactones with a carane system—insect feeding deterrents. Tetrahedron Asymmetry 2002, 13, 1761-1767. [CrossRef]

81. Steglich, W.; Hellwig, V. Revision of the structures assigned to the fungal metabolites boletunones A and B. Org. Lett. 2004, 6, 3175-3177. [CrossRef]

82. Engel, K.H.; Flath, R.A.; Buttery, R.G.; Mon, T.R.; Ramming, D.W.; Teranishi, R. Investigation of volatile constituents in nectarines. 1 . Analytical and sensory characterization of aroma components in some nectarine cultivars. J. Agric. Food. Chem. 1988, 36, 549-553. [CrossRef]

83. Ono, M.; Nagasawa, Y.; Ikeda, T.; Tsuchihashi, R.; Okawa, M.; Kinjo, J.; Yoshimitsu, H.; Toshihiro, N. Three new diterpenoids from the fruit of Vitex agnus-castus. Chem. Pharm. Bull. 2009, 57, 1132-1135. [CrossRef] [PubMed]

84. Macías, F.A.; Gallindo, J.L.G.; Valera, R.M.; Torres, A.; Mollinillo, J.M.G.; Fronczek, F.R. Heliespirones B and C: Two new plant heliespiranes with a novel spiro heterocyclic sesquiterpene skeleton. Org. Lett. 2006, 8, 4513-4516. [CrossRef] [PubMed]

85. Miles, C.O.; Wilkins, A.L.; Hawkes, A.D.; Jensen, D.J.; Selwood, A.I.; Beuzenberg, V.; Lincoln, M.A.; Cooney, J.M.; Holland, P.T. Isolation and identification of pectenotoxins-13 and -14 from Dinophysis acuta in New Zealand. Toxicon. 2006, 48, 152-159. [CrossRef] [PubMed] 
86. Jiang, J.S.; He, J.; Feng, Z.M.; Zhang, P.C. Two new quinochalcones from the florets of Carthamus tinctorius. Org. Lett. 2010, 12, 1196-1199. [CrossRef] [PubMed]

87. Byrne, L.T.; Guevara, B.Q.; Patalinghug, W.C.; Recio, B.V.; Ualat, C.R.; White, A.H. The X-ray crystal-structure of (+/-)-Pandamarine, the major alkaloid of Pandanus-amaryllifolius. Aust. J. Chem. 1992, 45, 1903-1908. [CrossRef]

88. Kosuge, T.; Zenda, H.; Ochiai, A.; Masaki, N.; Noguchi, M.; Kimura, S.; Narita, H. Isolation and structure determination of a new marine toxin, surugatoxin from the Japanese ivory shell, babylonia japonica. Tetrahedron Lett. 1972, 13, 2545-2548. [CrossRef]

89. Inoue, S.; Okada, K.; Tanino, H.; Hashizume, K.; Kakoi, H. Total synthesis of ( \pm )-surugatoxin. Tetrahedron 1994, 25, 2729-2752. [CrossRef]

90. Wang, J.; Chen, F.; Liu, Y.; Liu, Y.; Li, K.; Yang, X.; Liu, S.; Zhou, X.; Yang, J. Spirostaphylotrichin X from a Marine-Derived Fungus as an Anti-influenza Agent Targeting RNA Polymerase PB2. J. Nat. Prod. 2018, 81, 2722-2730. [CrossRef]

91. Masi, M.; Meyer, S.; Clement, S.; Andolfi, A.; Cimmino, A.; Evidente, A. Spirostaphylotrichin W, a spirocyclic $\gamma$-lactam isolated from liquid culture of Pyrenophora semeniperda, a potential mycoherbicide for cheatgrass (Bromus tectorum) biocontrol. Tetrahedron 2014, 70, 1497-1501. [CrossRef]

92. Luo, Q.; Di, L.; Dai, W.-F.; Lu, Q.; Yan, Y.-M.; Yang, Z.-L.; Li, R.-T.; Cheng, Y.-X. Applanatumin A, a New Dimeric Meroterpenoid from Ganoderma applanatum That Displays Potent Antifibrotic Activity. Org. Lett. 2015, 17, 1110-1113. [CrossRef]

93. He, J.; Feng, X.Z.; Lu, Y.; Zhao, B. Fomlactones A-C, novel triterpene lactones from Fomes cajanderi. J. Nat. Prod. 2003, 66, 1249-1251. [CrossRef] [PubMed]

94. Cheng, Z.-Y.; Du, Y.-Q.; Zhang, Q.; Lin, B.; Gao, P.-Y.; Huang, X.-X.; Song, S.-J. Two pairs of new alkaloid enantiomers with a spiro [benzofuranone-benzazepine] skeleton from the bark of Juglans mandshurica. Tetrahedron Lett. 2018, 59, 2050-2053. [CrossRef]

95. Li, L.; Peng, X.-R.; Dong, J.-R.; Lu, S.-Y.; Li, X.-N.; Zhou, L.; Qiu, M.-H. Rearranged lanostane-type triterpenoids with anti-hepatic fibrosis activities from Ganoderma applanatum. RSC Adv. 2018, 8, 31287-31295. [CrossRef]

96. Sun, N.; Zheng, G.; He, M.; Feng, Y.; Liu, J.; Wang, M.; Zhang, H.; Zhou, J.; Yao, G. Grayanane diterpenoids from the leaves of Rhododendron auriculatum and their analgesic activities. J. Nat. Prod. 2019, 82, 1849-1860. [CrossRef]

97. Li, J.; Ni, G.; Liu, Y.; Mai, Z.; Wang, R.; Yu, D. Seconoriridone A: A C16-seco-noriridal Derivative with a 5/5/7 Tricyclic Skeleton from Belamcanda chinensisI. Tetrahedron Lett. 2019, 60, 900-905. [CrossRef]

98. Xu, Y.-K.; Yang, S.-P.; Liao, S.-G.; Zhang, H.; Lin, L.-P.; Ding, J.; Yue, J.-M. Alkaloids from Gelsemium elegans. J. Nat. Prod. 2006, 69, 1347-1350. [CrossRef]

99. Kitajima, M.; Nakamura, T.; Kogure, N.; Ogawa, M.; Mitsuno, Y.; Ono, K.; Yano, S.; Aimi, N.; Takayama, H. Isolation of gelsedine-type indole alkaloids from Gelsemium elegans and evaluation of the cytotoxic activity of gelsemium alkaloids for A431 epidermoid carcinoma cells. J. Nat. Prod. 2006, 69, 715-718. [CrossRef]

100. Yang, C.B.; Zhang, F.; Deng, M.C.; He, G.Y.; Yue, J.M.; Lu, R.H. A new ellagitannin from the fruit of Phyllanthus Emblica L. J Chin Chem Soc. 2007, 54, 1615-1618. [CrossRef]

101. Selwood, A.I.; Wilkins, A.L.; Munday, R.; Shi, F.; Rhodes, L.L.; Holland, P.T. Portimine: A bioactive metabolite from the benthic dinoflagellate Vulcanodinium rugosum. Tetrahedron Lett. 2013, 54, 4705-4707. [CrossRef]

102. Fribley, A.M.; Xi, Y.; Makris, C.; Alves-de-Souza, C.; York, R.; Tomas, C.; Wright, J.L.; Strangman, W.K. Identification of portimine $\mathrm{B}$, a new cell permeable spiroimine that induces apoptosis in oral squamous cell carcinoma. ACS Med. Chem. Lett. 2018, 10, 175-179. [CrossRef]

103. Choodej, S.; Teerawatananond, T.; Mitsunaga, T.; Pudhom, K. Chamigrane sesquiterpenes from a basidiomycetous endophytic fungus XG8D associated with thai mangrove Xylocarpus granatum. Mar. Drugs 2016, 14, 132. [CrossRef] [PubMed]

104. Chen, X.Q.; Li, Y.; Peng, L.Y.; He, J.; Wang, K.; Pan, Z.H.; Cheng, X.; Li, M.M.; Zhao, Q.S.; Xu, G. Spirocyclic acylphloroglucinol derivatives from Hypericum beanii. Chem. Pharm. Bull. 2011, 59, 1250-1253. [CrossRef] [PubMed]

105. Wijeratne, E.M.K.; Espinosa-Artiles, P.; Gruener, R.; Gunatilaka, A.A.L. Thielavialides A-E, nor-spiro-azaphilones, and a bis-spiro-azaphilone from Thielavia sp. PA0001, an endophytic fungus isolated from aeroponically grown Physalis alkekengi. J. Nat. Prod. 2014, 77, 1467-1472. [CrossRef] [PubMed] 
106. Nong, X.H.; Wei, X.Y.; Qi, S.H. Pteridic acids C-G spirocyclic polyketides from the marine-derived Streptomyces sp. SCSGAA 0027. J. Antibiot. 2017, 70, 1047-1052. [CrossRef]

107. Guo, J.G.; Feng, Z.F.; Yang, Y.J.; Zhang, Z.Z.; Zhang, P.C. Pollenopyrroside A and B, novel pyrrole ketohexoside derivatives from bee-collected Brassica campestris Pollen. Chem. Pharm. Bull. 2010, 58, 983-985. [CrossRef]

108. Wang, W.L.; Zhu, T.J.; Tao, H.W.; Lu, Z.Y.; Fang, Y.C.; Gu, Q.Q.; Zhu, W.M. Three novel, structurally unique spirocyclic alkaloids from the halotolerant B-17 fungal strain of Aspergillus variecolor. Chem. Biodivers. 2007, 4, 2913-2919. [CrossRef]

109. Zhong, W.; Wang, J.; Wie, X.; Chen, Y.; Fu, T.; Xiang, Y.; Huang, X.; Tian, X.; Xiao, Z.; Zhang, W.; et al. Variecolortins A-C, three pairs of spirocyclic diketopiperazine enantiomers from the marine-derived fungus Eurotium sp. SCSIO F452. Org. Lett. 2018, 20, 4593-4596. [CrossRef]

110. Bai, M.; Zheng, C.-J.; Huang, G.-L.; Mei, R.-Q.; Wang, B.; Luo, Y.-P.; Zheng, C.; Niu, Z.-G.; Chen, G.-Y. Bioactive meroterpenoids and isocoumarins from the mangrove-derived fungus Penicillium sp. TGM112. J. Nat. Prod. 2019, 82, 1155-1164. [CrossRef]

111. Jones, T.H.; Adams, R.M.M.; Spande, T.F.; Garraffo, H.M.; Kaneko, T.; Schultz, T.R. Histrionicotoxin alkaloids finally detected in an ant. J. Nat. Prod. 2012, 75, 1930-1936. [CrossRef]

112. Wang, L.Y.; Qin, J.J.; Chen, Z.H.; Zhou, Y.; Tang, W.; Zuo, J.P.; Zhao, W.M. Absolute configuration of periplosides $\mathrm{C}$ and $\mathrm{F}$ and isolation of minor spiro-orthoester group-containing pregnane-type steroidal glycosides from Periploca sepium and their T-lymphocyte proliferation inhibitory activities. J. Nat. Prod. 2017, 80, 1102-1109. [CrossRef]

113. Mackinnon, S.L.; Walter, J.A.; Quilliam, M.A.; Cembella, A.D.; LeBlanc, P.; Burton, I.W.; Hardstaff, W.R.; Lewis, N.I. Spirolides isolated from Danish strains of the toxigenic dinoflagellate Alexandrium ostenfeldii. J. Nat. Prod. 2006, 69, 983-987. [CrossRef] [PubMed]

114. Xie, Y.; Zhong, X.; Xiao, Y.; Zhu, S.; Muhammad, I.; Yan, S.; Jin, H.; Zhang, W. Vieloplains A-G, seven new guaiane-type sesquiterpenoid dimers from Xylopia vielana. Bioorg Chem. 2019, 102891. [CrossRef] [PubMed]

115. Song, J.; Liu, Y.; Zhou, M.; Cao, H.; Peng, X.G.; Liang, J.J.; Zhao, X.Y.; Xiang, M.; Ruan, H.L. Spiroschincarins A-E: Five spirocyclic nortriterpenoids from the fruit of Schisandra incarnate. Org. Lett. 2017, 19, 1196-1199. [CrossRef] [PubMed]

116. Sun, M.-X.; Cui, Y.; Li, Y.; Meng, W.-Q.; Xu, Q.-Q.; Zhao, J.; Lu, J.-C.; Xiao, K. Indole alkaloids from Gelsemium elegans. Phytochemistry 2019, 162, 232-240. [CrossRef] [PubMed] 